Research Square
Preprints are preliminary reports that have not undergone peer review.

They should not be considered conclusive, used to inform clinical practice, or referenced by the media as validated information.

\title{
Systematic Review of The Effect of Upper Airway Surgery Based on DISE Findings In Adults With Obstructive Sleep Apnea
}

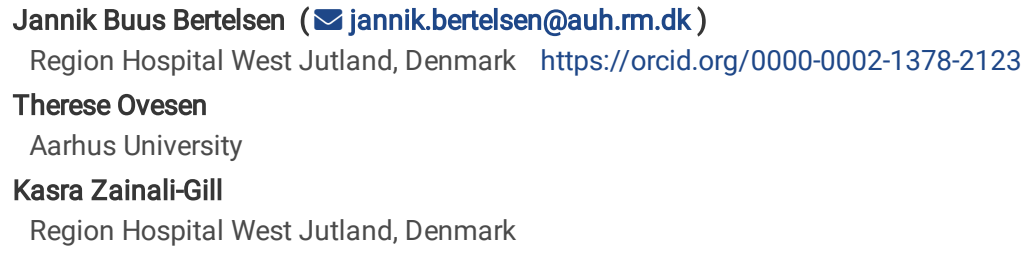

\section{Research}

Keywords: Adults, apnea / hypopnea index, drug induced sedation endoscopy, obstructive sleep apnea, upper airway surgery.

Posted Date: September 14th, 2021

DOI: https://doi.org/10.21203/rs.3.rs-818197/v1

License: (c) (1) This work is licensed under a Creative Commons Attribution 4.0 International License. Read Full License 


\section{Abstract}

The objective of this review is to evaluate the effectiveness of upper airway surgery in adults with OSA verified on Drug Induced Sedation Endoscopy (DISE) and evaluated by change in AHI with minimum 3 month's follow-up.

\section{Introduction:}

Obstructive sleep apnea (OSA) is common among adults worldwide and is associated with an increased risk of cardiac and metabolic disease. However, the evidence of the different types of upper airway surgery to relieve OSA symptoms are sparse.

\section{Inclusion criteria:}

Inclusion criteria for this review were randomized controlled trials, prospective and retrospective studies case-control studies and cohort studies on one or a combination of surgeries on the upper airways in adults diagnosed with OSA and obstruction verified by DISE before surgery. AHI should be reported prior to and minimum 3 months after surgery by polysomnography or home sleep apnea test and a minimum of 40 participants published from year 2000 to December 2019. All surgeries in upper airways including soft tissue of the retropharyngeal space, velum, tonsils and base of tongue were included. Surgeries on cartilage and bone as septoplasty, turbinoplasty, mandibular advancement surgery, epiglottoplasty and tracheostomy were included plus hypoglossal nerve stimulation implant.

Exclusion criteria were reviews supplying no data, case reports and studies reporting treatment mandibular advancement devices or position trainer. Surgeries targeting other anatomical sites than upper airways with a known reduction in AHI as bariatric surgery were also excluded. Studies without pre-operative DISE were excluded. Publications in other language than English were excluded.

\section{Methods:}

Cochrane, PubMed, CINAHL and Embase were systematically searched on December 12th, 2019. Abstracts in languages other than English were deselected. Relevant studies were selected on their abstracts and full texts were obtained for critical appraisal. Relevant data were extracted for data synthesis. The reference list of all studies selected for critical appraisal was screened for additional studies.

\section{Results (For Reviews ONLY):}

Studies were excluded due to small sample size, lack of postoperative AHI and because DISE was not a part of preoperative evaluation. Ten studies were finally included for review. These could be divided into three segments, comprised by three studies for surgeries of the velum and oropharynx, four studies addressing the base of tongue (BOT) and three studies in multi-level surgery.

Velum and oropharynx surgery led to an AHI-decrease of $11.86,95 \% \mathrm{Cl}(10.21 ; 13.51)$ event per hour. ESS was reduced 7.01 (5.99; 8.04$)$. In BOT surgery AHI was reduced $19.31(17.81 ; 20.81)$ events/hour and ESS decreased with $7.03(6.44 ; 7.63)$. Multilevel surgery reduced AHI with 28.65 (24.60, 32.69$)$ events/hour and ESS with $8.55(6.73 ; 10.38)$.

\section{Conclusions:}

Our review indicated that incorporating DISE in the preoperative evaluation of OSA patients, improved the selection of patients for specific upper airway surgeries, causing a better surgical outcome measured by a reduction in AHI and ESS. We found the literature to be primarily comprised of case series with few numbers of patients and a wide variety of approaches to pre-operative evaluation and post-operative follow up.

\section{Introduction}

Obstructive sleep apnea (OSA) is a common condition among adults worldwide $34 \%$ in men aged $30-70$ years and $17 \%$ in women aged $30-70$ years [1]. The negative effects of OSA such as increased risk of cardiac and metabolic disease are well known-documented[2]. Continuous positive airway pressure (CPAP) is considered first line treatment in preventing upper airway collapse, improving sleep, and reducing daytime sleepiness ${ }^{\star \star \star}$. However, two systematic literature reviews found significant low level of compliance reported as non-adherence levels of $34.3 \%$ to CPAP therapy[3] and as high as $29 \%$ to $83 \%[4]$. Hence alternatives for CPAP and lifestyle changes are explored. Various treatments are used from lifestyle changes through sleep position treatment, oral mandibular device, bariatric surgery to different types of upper airway surgery to relieve symptoms of OSA or to increase compliance to CPAP.

Drug induced sedation endoscopy (DISE), originally described in 1991 by Croft and Pringle [5], is an interesting examination in the clinical evaluation of the individual anatomical abnormalities before upper airway surgery to reduce OSA. DISE has been validated to be relevant prior any sleep surgery [6-8]. This review investigated the evidence of different types of upper airway surgeries to relieve OSA symptoms when DISE was included in the preoperative evaluation in the planning of the possible surgical approaches.

A preliminary search of PROSPERO, MEDLINE, the Cochrane Database of Systematic Reviews and the JBI Database of Systematic Reviews and Implementation Reports was conducted and no current or underway systematic reviews on the topic were identified. A systematic review regarding hypoglossal nerve stimulation was identified[9]. Two systematic reviews regarding transoral robotic surgery (TORS) was identified[10,11]. However, this review emphasizes on DISE as part of preoperative work up and it involves sleep related surgical principles of the upper airway with follow-up period of at least 3 months. 
A Cochrane review on the effect of upper airway surgery for OSA measured by change in AHI from 2005 found a limited number of trials assessing diverse surgical techniques. The effects reported across the trials were inconsistent. The evidence from the small studies did not support the use of surgery in people with mild to moderate daytime sleepiness associated with sleep apnea[12].

Based on a protocol from 2017, an updated Cochrane Review on surgical treatment of obstructive sleep apnea is being constructed but it has not been published. This review seems to have a focus on change in AHI and in ESS but does not incorporate DISE prior to surgery [13].

The purpose of this review was to evaluate the effectiveness of upper airway surgery in adults with OSA verified on DISE and evaluated by change in AHI with a minimum of 3 months follow-up.

\section{Review question(s)}

The question of this review was: How is the effect of different types of upper airway surgery measured by change in AHI in adults with obstructive sleep apnea when Drug-induced Sedation Endoscopy is used for selecting the surgery?

\section{Inclusion criteria}

\section{Participants}

Inclusion criteria for this review are adult patients older than 18 years with diagnosed OSA either by polysomnography or by home sleep test. Follow-up time is 3 months or longer. Surgery is performed after DISE and the surgery should address the obstruction confirmed by DISE.

Exclusion criteria are case reports, reviews reporting no data and studies with less than 40 participants or studies reporting treatment with oral appliance therapy (OAT) / mandibular advancement devices (MAD), position trainer or bariatric surgery.

\section{Outcomes}

Primary outcomes in this review are changes in apnea-hypopnea index (AHI), defined by the number of apnea and hypopnea events per hour of sleep, before and minimum 3 months after surgery to evaluate surgical success and surgical response or success defined by Sher's criteria [14] defined as the reduction of $\mathrm{AHI}>50 \%$ and to a value of less than 20 events per hour. Epworth Sleepiness scale (ESS) is used for measuring Patient related outcome.

Secondary outcomes such as oxygen desaturation index (ODI), nadir peripheral oxygen saturation (SpO2), snoring scales, social and functional questionnaires, and other outcomes are described in the results.

\section{Types of studies}

This review considers both experimental and quasi-experimental study designs including randomized controlled trials, non-randomized controlled trials, before and after studies and interrupted time-series studies. In addition, analytical observational studies including prospective and retrospective cohort studies, casecontrol studies and analytical cross-sectional studies are considered for inclusion. The systematic review includes English written randomized controlled trials, prospective and retrospective case-control studies, and cohort studies on one or a combination of surgeries on the upper airways in adults diagnosed with OSA and obstruction verified by DISE before surgery. Sample size was minimum 40 participants. AHI should be reported prior to and minimum 3 months after surgery by polysomnography or home sleep apnea test. Publications from January $1^{\text {st }} .2000$ to December $11^{\text {th }} .2019$ were included. Surgery of the upper airways, including soft tissue of the retropharyngeal space, velum, tonsils, epiglottis, and base of tongue are included. Septoplasty and turbinoplasty are also included as well as the novel implant techniques with hypoglossal nerve stimulation. Maxillomandibular advancement surgery and hyoid suspension surgery are also included in the review of the literature. This review excluded descriptive observational study designs including case series, individual case reports and descriptive cross-sectional studies.

\section{Methods}

The systematic review is conducted in accordance with the Joanna Briggs Institute methodology for systematic reviews of effectiveness evidence [15,16]

\section{Search strategy}

The electronic search strategy was designed and conducted by an experienced reference librarian based on input from the study investigators.

An initial limited search of MEDLINE and CINAHL was undertaken to identify articles on the topic. The text words contained in the titles and abstracts of relevant articles, and the index terms used to describe the articles were used to develop a full search strategy for Cochrane, MEDLINE, CINAHL and Embase. (see Appendix \#). The search strategy, including all identified keywords and index terms, will be adapted for each included information source. The reference list of all studies selected for critical appraisal was screened for additional studies. 
To identify eligible studies published in English, the electronic databases (MEDLINE, EMBASE, CINAHL and COCHRANE were searched for studies published from January 1st 2000 to December 11th 2019 cross referencing the key words obstructive sleep apnea, sleep apnea AND septoplasty, turbinoplasty, hyoid suspension, epiglottoplasty and tracheostomy, veloplasty, uvulapalatopharyngoplasty(UPPP), Laser-assisted Uvuloplasty (LAUP), palatal radiofrequency ablation (RFA), palatal implants, lateral expansion pharyngoplasty, expansion sphincter pharyngoplasty (ESP), Z-palatoplasty, tonsillectomy, tonsillotomy, adenoidectomy, RFA of tongue base, tongue base resection or reduction, mandibular advancement surgery, hypoglossal nerve stimulation (UAS).

\section{Study selection}

Following the search, all identified citations were collated and uploaded into Rayyan and duplicates were removed [17]. Titles and abstracts was then screened by two independent reviewers for assessment against the inclusion criteria for the review.

Potentially relevant studies were retrieved in full and their citation details imported into the Joanna Briggs Institute System for the Unified Management, Assessment and Review of Information (JBI SUMARI) (Joanna Briggs Institute, Adelaide, Australia) [18]

The full text of selected citations was assessed in detail against the inclusion criteria by two independent reviewers. Reasons for exclusion of full text studies that did not meet the inclusion criteria were noted and reported in the systematic review. Any disagreements that arise between the reviewers at each stage of the study selection process were resolved through discussion, or with a third reviewer. The results of the search were reported in full in the final systematic review and presented in a Preferred Reporting Items for Systematic Reviews and Meta-analyses (PRISMA) flow diagram[19].

\section{Assessment of methodological quality}

Eligible studies were critically appraised by two independent reviewers at the study level. Authors of papers was contacted to request missing or additional data for clarification, where required. Any disagreements that arise was resolved through discussion, or with a third reviewer. Following critical appraisal, studies that do not meet a certain quality threshold were excluded. The included studies are reported in narrative form and in a table.

\section{Data extraction}

Data extracted from studies was included in the review by two independent reviewers using the standardized data extraction tool. The data extracted included specific details about the populations, study methods, interventions, and outcomes of significance to the review objective.

\section{Data synthesis}

The meta-analysis was performed in a statistical software Cran-R-4.0.3 using the package 'metafor'. The estimates for change from pre to post-operative effect and their $95 \%$ confidence intervals were calculated using fixed effect model with inverse of the variance as weights. Since majority of the studies have not reported the results from which standard deviation for the mean change in AHI from pre to post can be calculated, zero correlation between the pre and post measurements were assumed and hence the reported $95 \%$ confidence intervals could be broader than their actual width.

The data was divided into three groups, each specific for the level of obstruction addressed, either velum/oropharynx (soft palate), base of tongue or multilevel surgery.

\section{Soft palate surgery}

Soft palate surgery aims to reduce and reconstruct the part of the soft palate which often collapses during obstructive sleep apnea. A procedure initially known as classical uvulopalatopharyngoplasty (UPPP), first described by Fujita [19]. It involves the removal of both tonsils and the posterior soft palate and uvula, and the closure of the tonsillar pillars has evolved. Different techniques such as modified UPPP which involves removal of additional mucosa and submucosal adipose tissue [20], expansion sphincter pharyngoplasty (ESPL) first described by Pang and Woodson [21] which includes the transection of the palatopharyngeal muscle, rotating the muscle superior-laterally to mobilize it and then suture it to the pterygomandibular raphe through a mucosal tunnel to create a broader widening of the pharyngeal space. Further techniques such as barbed wire stitch reposition [22], the use of radiofrequency ablation of the soft palate [23] or laser assisted uvulopalatoplasty [24] are also well known and used to treat retropharyngeal collapse of the upper airway. The use of implants to stiffen the soft palate is also used in different settings. A thorough description of these techniques is not within the scope of this paper. However, it is noticed that that some techniques are used in an out-patient clinical setup, others as full operations in general anesthesia and some techniques occurs in multi-level surgery, whereas some only occurs as single-step surgery.

Furthermore, some procedures are offered to patients with severe OSA where AHI is high, others in mild or moderate OSA. Clinical features such as comorbidity, BMI, tonsil size, the positioning of the soft palate, the narrowing of the pharyngeal wall, neck circumference, the collapses of upper airway observed during DISE are used, however not all available studies present these findings, nor do many studies follow a uniform standardized approach. This review found three studies investigating the effect of soft palate surgery eligible for this systematic review.

Base of tongue 
Besides the treatments offered to address the velopharyngeal and the lateral wall of the oropharynx collapses, a variety of procedures devised to address the hypopharynx and the base of the tongue have been investigated. Procedures such as genioglossus advancement[25], radiofrequency tissue ablation of the tongue base [26], suturing of the tongue base and hyoid suspension are described [27], however the studies are often case reports or retrospective studies with few subjects and a limited follow-up time. The introduction of transoral robotic surgery (TORS) and the advancements in tongue base resections initially in cancer surgery has evolved into also using TORS in sleep surgery [28]. Furthermore, the introduction of the hypoglossal nerve stimulation termed upper airway stimulation (UAS) is interesting [29]. The insertion of a unilateral stimulation lead attached to the branch of the hypoglossal nerve, thereby producing tongue protrusion synchronous with expiration during sleep. The impulse generator is implanted beneath the clavicle and a tunneled breathing sensing lead is placed between the external and intercostal muscles. One could advocate that UAS is a multilevel treatment modality, since postoperative DISE findings indicates improvements in the retropalatal obstruction as well. However, the treatment is indicated in OSA with a primarily retro-lingual obstruction, this systematic review has categorized this treatment to the treatment of base of tongue.

This review found four studies eligible for a systematic review targeting treatment on the base of the tongue:

Multi-level surgery

As described previously, OSA is often associated with multi-level collapse of the upper airways, hence multilevel surgery is also necessary and introduced as a treatment opportunity. The benefits and disadvantages of single-step and multi-step surgical intervention is beyond the scope of this review. Some surgeons advocate that nasal surgery is performed prior to any direct approach towards the soft palate, lateral wall of the oropharynx or the base of tongue is considered. This review found three eligible studies investigating multi-level surgery as a single-step procedure.

This review did not consider nasal surgery as a part of multi-level approach.

\section{Results}

Ten studies were included and divided in three subcategories covering the site of obstruction, which were retropharyngeal collapse, base of tongue and multilevel surgery. In total we included 697 adult patients older than 18 years with an average age of 50,4 years. Average BMI was 28,98 . A summary of studies are presented in table 1.

Most studies included patients with moderate to severe OSA, however the definition was either AHI above 15 or AHI above 20. Plaza et. al and Amali et. al included patients with mild OSA (5>AHI<15) as well. Due to the heterogeneity of the procedures and the variation of follow-up time, the results are described in a narrative form and presented in table 2 .

Velum and oropharynx surgery led to a decrease in AHI of $11.86(10.21 ; 13.51)$ event/hour. ESS was reduced 7.01 (5.99; 8.04$)$. In BOT surgery AHI was reduced $19.31(17.81 ; 20.81)$ events/hour and ESS decreased with $7.03(6.44 ; 7.63)$. Multilevel surgery reduced AHI with 28.65 (24.60, 32.69) events/hour and ESS with $8.55(6.73 ; 10.38)$. All secondary outcome results are presented in table 2 .

A detailed description of the articles based on the level of obstruction follows beneath.

\section{Soft palate surgery:}

Plaza et. al. 2019[30]

Plaza et. al. presented a prospective non-comparative multi-center study of patients suffering from OSA selected to ESP as stand-alone procedure at three University Hospitals. Patients diagnosed with OSA with preoperative AHI 5-70, age between 18 and 70, BMI < 35, and predominant lateral wall collapse on oropharynx during DISE were included. If nasal procedures were necessary, this was performed before, at a different stage than pharyngeal surgery. Seventyfive patients were included. Baseline characteristics including clinical findings such as tonsil size, Friedman tongue position (FTP), lingual tonsil hypertrophy (LTH). Both preoperative and postoperative data as AHI and ESS were reported. Follow-up was at least 12 months with clinical exam, including PSG and ESS. Surgical success was reported using Sher criteria described as: Cured $=\mathrm{AHI}<5$ and ESS $<10$ or AHI reduction $>50 \%$. The need for CPAP after surgery was defined as $\mathrm{AHI}<15$ and $\mathrm{ESS}<10$ and reduction $>50 \%$.

The study showed a statistically significant reduction in mean AHI $13.50(10.35 ; 16.65)$ and a statistically significant reduction in mean ESS 6.90 (5.07; 8.73$)$.

\section{Amali et. al. 2017[31]}

Amali et. al. compared UPPP with radiofrequency ablation of the soft tissue in 40 patients with mild to moderate OSA in a randomized clinical trial. Patients with mild to moderate OSA ( $\mathrm{AHI}>5$ and $\mathrm{AHI}<30$ ) with DISE findings suggesting velopharyngeal or oropharyngeal lateral wall collapse were included. BMI above 35 , tongue base or epiglottis obstruction or severe comorbidities were reasons for exclusion. Patient baseline characteristics including clinical findings such as tonsil size, FTP, use of tobacco and blood pressure were reported. Detailed follow-up time was not reported, however the study states that follow-up was 6 months. Postoperative AHI, postoperative ESS and postoperative nadir 02 saturation was reported. Furthermore, all patients completed the Sleep Apnea Quality of Life Index questionnaire (SAQLI). Treatment success was defined as $>50 \%$ reduction in AHI from baseline.

The study reported a statistically significant reduction in AHI in both groups (UPPP $10.12(6.76 ; 13.48)$ (MRFTA 6.03 (2.77; 9.29)) and a statistically significant reduction in ESS (UPPP $5.20(3.29 ; 7.11)$ ) and (MRFTA $5.73(2.99 ; 8.47))$. Furthermore, they found a statistically significant improvement in mean SpO2 nadir in both groups. The postoperative AHI was significantly lower in the UPPP group compared to MRFTA group $(p=0,02)$. Surgical success rate in the UPPP group was significantly higher than in the MRFTA group, $73 \%$ versus $40 \%(p=0,03)$. For ESS and mean SpO2 nadir they found no statistically significant differences

Page 5/22 
between the two groups.

Quality of life reported with SAQLI improved in both groups and reported higher in MFRTA group in two domains including social interaction and treatmentrelated symptoms.

Hong et. al. 2019[32]

Hong et. al. reported a retrospective cohort study of 63 patients with OSA diagnosed with isolated lateral pharyngeal collapse during DISE. Patients diagnosed with moderate to severe OSA (35\% and 65\% respectively) underwent Expansion Sphincter Pharyngoplasty (ESPL) including bilateral tonsillectomy, removal of uvula mucosa and reduction of the uvula tip. All patients had nasal obstruction and received either turbinoplasty or combined septoturbinoplasty. Detailed follow-up time was not reported, however the study states that follow-up was 6 months. Postoperative AHI, postoperative ESS and postoperative SpO2 nadir was reported.

Patient selection was based upon DISE findings such as retropalatal circumferential narrowing above DISE grade II (more than $75 \%$ narrowing) and narrowed oropharynx due to lateral pharyngeal collapse of the bulky redundant soft tissue around the posterior pillars. The patients did not have obstruction at the tongue base or epiglottis. Clinical findings such as tonsil sizes, Friedman tongue position scale or neck circumferential were not reported, nor were patient baseline characteristics described.

The study reported a statistically significant reduction in AHI $18.20(14.76 ; 21.64)$ and ESS $9.90(7.87 ; 11.93)$. Limitations were the use of nasal surgery in all patients, however all patients had moderate to severe OSA, and nasal surgery is not considered to improve moderate to severe OSA, hence is not considered to be a part of multi-level sleep surgery.

\section{Base of tongue:}

\section{Babademez et. al. 2019[33]}

Babademez et. al. reported a prospective randomized study and comparison of robotic tongue base resection vs coblation tongue base resection. Patients with moderate to severe OSA reported by PSG, tonsil size 1-2 and BMI < 35 and isolated tongue base obstruction diagnosed during DISE preoperatively, were randomized in either robotic group (TORS) or coblation group. The randomization was done in the operating room. One surgeon performed all robotic treatments, and another surgeon performed all coblation treatments. Clinical findings were not reported; however, inclusion and exclusion parameters include clinical findings. Previous tonsillar surgery, limited mouth opening, and severe comorbidities were exclusion parameters. Seventy-seven patients were included and randomized to the study. Four patients were excluded due to perioperative complications of anesthesia. Three patients (two in TORS group and 1 in coblation group) were lost to follow-up. Follow-up time was 6 months. Post-operative AHI, ESS and snoring VAS were reported and compared to preoperative data. Operation time, time to oral diet in days and the length of analgesia needed postoperative were also reported.

The study reports a statistically significant reduction in mean AHI with a $36 \%$ reduction in TORS group $(19.00(15.84 ; 22.16))$ and $37.8 \%$ reduction in coblation group $(16.90(14.33 ; 19.47))$. A statistically significant reduction in ESS was also reported with $33.8 \%$ reduction in the TORS group (8.00 (6.94; 9.06$)$ and $31.5 \%$ in the coblation group $(7.80(6.76 ; 8.84])$. No statistically significant differences were seen between the two groups in any outcome parameters, however coblation was associated with quicker recovery and lower complication risks.

Strollo et. al. 2014[34]

The Stimulation Therapy for Apnea Reduction (STAR) trial presented by Strollo et. al. was pivotal regarding UAS therapy in patients with moderate to severe OSA. This led to FDA approval of the device and hence multiple studies have been published also in Europe with concurrent results. Strollo et. al. presents a multi-center prospective cohort study with 126 adult patients implanted with a unilateral hypoglossal nerve stimulator with a follow-up time of 12 months. Patients were carefully selected by inclusion criteria based upon previous feasibility studies. The first 46 consecutive patients after 12 months were randomized 1:1 and 23 patients were selected to a therapy-withdrawal group with deactivation of the implant and thereby used as a control group.

Primary outcomes were AHI and oxygen desaturation index (ODI) by PSG and secondary outcomes such as ESS and disease-specific quality of life assessed by the Functional Outcomes of Sleep Questionnaire (FOSQ) were reported. Patient baseline data and comorbidities, previous surgery such as uvulopalatopharyngoplasty and blood pressure were reported. Follow-up at two months and six months were performed but not stated. The implants were activated one month postoperatively. Surgical response was defined as Sher's criteria at 12 month's follow-up. Furthermore, surgical response was defined as at least $25 \%$ reduction in ODI and reported. Two patients were lost to follow-up and considered non-responders.

The study showed a statistically significant reduction in mean AHI of 16.70 (13.19; 20.21 . Surgical responders based upon AHI were 83 of 126 patients (66\%) and based upon ODI was 94 of 126 patients (75\%). Mean ESS and mean FOSQ were also statistically significantly improved.

The therapy-withdrawal study showed a significant difference between the withdrawal group and the therapy-maintenance group with respect to the change in $\mathrm{AHI}$ from the beginning of the randomization to

the assessment 1 week later. In the withdrawal group, baseline AHI was 30,1 events per hour, before deactivation 7,6 events per hour and after deactivation 25,8 events per hour, whereas the maintenance group reported baseline AHI 31,3 events per hour, at randomization 7,2 events per hour and 1 week later 8,9 
events per hour. Similar effects in ODI were reported in the study.

Adverse events were reported. Two patients had severe device-related adverse events which required repositioning and fixation of the neurostimulator. Other mild adverse events are also described in the study.

The study concludes that UAS showed a reduction in the severity of obstructive sleep apnea, and the adverse-event profile was acceptable. In 2018 -year follow-up in the same group was published by Woodson et. al. (REF). Although only 71 patients had PSG at 5-year follow-up, the results were unchanged. Since the study is based upon the same group, the data is not included in this review.

Huntley et al. 2017[35]

Upper airway stimulation for treatment of OSA was also investigated by Huntley et. al and outcomes of two academic centers were compared. Patients from two different centers with 63 patients and 57 patients, respectively. Group 1 had a mean follow-up time of 90.39 days and group 2 had a mean follow-up time of 85.23 days. Although the study does not entirely fulfill the statement of minimum 3-month follow-up in this systematic review, the papers level of evidence is high and the study is the first non-industrial funded study with large number of patients, who have undergone UAS following the commercial availability of the device. Therefore, we found it compelling to include the study in the review.

Patients who completed postoperative PSG titration and outpatient follow-up were included in the study, which consisted of 48 patients and 49 patients respectively in the two groups. Baseline demographic data such as sex, age and BMI were reported. Baseline and postoperative AHI, ESS and SpO2 nadir were reported. Patients were included with the same criteria defined and published by Strollo et. al. (2014)[34] including DISE findings and the lack of concentric retropalatal collapse. Patient outcome from each group were analyzed individually and afterwards pooled. Surgical success followed Sher's criteria and defined as reduction of $\mathrm{AHI}>50 \%$ and to a value of less than 20 events per hour.

The study showed statistically significant improvements in AHI (H-48 (29.54 (22.81; 36.27]) vs H-49 (29.01 24.39; 33.63$))$, ESS (H-48 (5.32 (3.89; 6.75$))$ and (H$49(4.34(1.97 ; 6.71))$ and nadir 02 saturations in both groups, although the nadir 02 saturation in group 1 was better than in group 2 . Surgical success was illustrated in the study's figure 1 and reported around $90 \%$ of patients in both groups with no statistically significant differences between the two groups. The figure also illustrates the percentage of patients with $\mathrm{AHI}<15, \mathrm{AHI}<10$ and $\mathrm{AHI}<5$ at each institution.

The study concluded that UAS is an effective alternative treatment in a subset of patients with moderate to severe OSA with base of tongue collapse, who were unable to comply with CPAP therapy.

Steffen 2018[36]

Upper airway stimulation of the hypoglossal nerve in patients with moderate to severe OSA has been investigated in a European setting by Steffen et. al. A multi-center prospective study with 60 patients in three German centers was conducted. Data from 6-month follow-up was reported by Heiser et. al. in 2016[37], however the latest report from Steffen et. al. is included in this review due to longer follow-up. Four patients did not complete the 12-month followup, one patient requested implant removal due to personal matters and three were lost to follow-up.

Patient baseline data such as age, BMI and sex were reported. Preoperative and postoperative therapy outcome AHI was reported using 2-night home sleep test. Follow-up was 6 months and 12 months after implantation. Implants were activated one month postoperatively. Two months after implantation, in-lab titration during PSG was performed to optimize the implant therapy. Primary outcomes were AHI postoperatively and secondary outcomes were ESS and Function Outcomes of Sleep Questionnaire (FOSQ) at 6 and 12 months. ODI, Sp02 nadir and mean SpO2 were also reported. Patients defined as surgical response and surgical success were also reported in line with Sher's criteria. The data was also compared to the STAR data reported by Strollo et. al. The study reported both mean and standard deviations, as well as median values with interquartile range. For comparison reasons, only mean values and SD values are reported in this review.

The study showed at statistically significant reduction in mean AHI $17.40(12.38 ; 22.42)$ at 6 -month follow-up and the improvement was unchanged at 12 month's follow-up. Improvements in ODI, SpO2 nadir, mean ESS $6.30(4.54 ; 8.06)$ and mean FOSQ was also statistically significant. At the end of the study, $30 \%$ of the patients were cured. $68 \%$ of the patients were considered as surgical responders. Patients lost to follow-up was regarded as non-responders. Comparison of surgical responders and non-responders showed no differences in baseline data such as age, BMI, neck circumference, AHI, ODI, FOSQ or ESS The results were consistent with previous reported outcome by the STAR trial. The study concludes that UAS is a safe and feasible therapy capable to reduce OSA severity and prove patient reported quality of life outcomes, and therapy adherence was high after 12 months of follow-up.

\section{Multi-level surgery:}

\section{Cammaroto et. al. 2018[38]}

Cammaroto et. al. evaluated in a retrospective study both the influence of the volume of excised base of tongue on the surgical outcome after TORS and the role of the lymphatic or muscular predominance within the removed tissue. The premise for the study was a meta-analysis by Meccariello and Cammaroto showing promising results for TORS [39]. Although no correlations between the excised volume of the tongue base, the lymphatic/muscular ratio of removed tissue or total thickness of tongue base and AHI changes could be shown, the overall reduction in AHI in patients with moderate to severe OSA was reported and shown to be statistically significant $24.87(19.31 ; 30.43)$.

The study consists of 51 patients who underwent single-step multi-level TORS including temporary tracheostomy, tonsillectomy, expansion sphincter pharyngoplasty and septoturbinoplasty and base of tongue excision. Patient characteristics such as age, gender, BMI, and preoperative and postoperative AHI

Page $7 / 22$ 
were reported. Furthermore, mean tongue volume (cc), lymphatic/soft tissue ratio, total thickness of removed base of tongue and success rate were reported. Surgical response was defined accordingly to Sher's criteria.

No correlations were observed in postoperative $\mathrm{AHI}$ and anatomical measures of removed base of tongue tissue. Although the study did not show any differences in the primary measured outcomes, the observed reduction of AHI was found to be statistically significant and the rate of surgical success reported, concur with previous studies published.

\section{El-Anwar et. al. 2018[40]}

El-Anwar published a prospective non-randomized study with 40 patients scheduled for multilevel surgery. Surgery was multi-level surgery including hyoid suspension, tonsillectomy and pharyngeal suspension sutures described by El-Ahl and El-Anwar [41]. Group A consisted of patients with nasal obstruction and underwent inferior turbinate reduction), while group B did not. Postoperative follow-up was between 6 months and 14 months postoperatively. Patient baseline characteristics such as age, gender and BMI were reported. Primary outcome was AHI. Preoperative and postoperative data such as ESS and nadir oxygen saturation was also reported.

The preoperative and postoperative data was not tested within the groups. Between the groups, preoperative AHI was significantly higher in patients with nasal obstruction (group A) compared to patients with no nasal obstruction (group B) and the reduction in AHI was greater in group A than in group B (43.90 $(31.83 ; 55.97)$ vs $23.30(8.84 ; 37.76)$ respectively. No difference in the change in ESS between group $A$ and $B(8.50(5.78 ; 11.22)$ and $8.60(6.13,11.07)$.

The study suggests that nasal obstruction, although not pivotal in treating OSA, is beneficial in a multi-level treatment setup, as the decrease in AHI in group A is larger than in group B. Unfortunately, the study setup is not optimal to investigate this question, since a group of patients with nasal obstruction without nasal surgery is lacking.

Thaler et. al 2016[42]

Thaler et. al. reported the effect of TORS in a prospective, non-randomized trial with historical controls, a study with 75 adult patients with moderate to severe OSA with AHI > 20, and who had failed CPAP. This study did not exclude patients with any prior airway surgery such as tonsillectomy or UPPP. The study did not have any maximum AHI or BMI. DISE was performed in all patients and patients with retro-lingual collapse underwent TORS. Patients with simultaneous retropalatal collapse were offered UPPP, if not performed previously. A historical cohort of previous UPPP surgery was used as comparison. All patients undergoing TORS and UPPP had both procedures as single-step surgery, TORS was performed first. Postoperative follow-up including PSG and ESS evaluation was done at a minimum of 3 months. Detailed follow-up time was not reported. Surgical response and surgical success rates were defined as Sher's criteria like other studies and reported. Patient baseline data were not reported. Preoperative and postoperative AHI, ESS and SpO2 nadir were also reported. Group 1 were 45 patients with no prior surgery and received TORS and UPPP surgery. Group 2 were 31 patients with prior surgery (tonsillectomy or UPPP).

The study found a statistically significant reduction in mean AHI in group A 38.90 (29.97; 47.83), whereas the decrease in AHI in group 2 (mean 10.00 , (95\% Cl; $4.77 ; 24.77)$ ) was not statistically significant. The improvements in SpO2 nadir was not statistically significant when each group was analyzed. When data was pooled, the improvements in $\mathrm{AHI}$ and SpO2 nadir were statistically significant. Looking at surgical response and surgical success, 25 patients (56\%) in group 1 had surgical success, 8 patients (17\%) with surgical response and 12 patients $27 \%$ ) were considered as failures, while in group 2, nine patients (30\%) had surgical success, three patients (10\%) were responders, and 18 patients $(60 \%)$ were failures.

The study concludes that TORS and UPPP is safe, and the results provide evidence in favor of multilevel approach, however there is still a significant percentage of patients for whom surgery does not improve OSA and therefore improved preoperative screening is necessary.

\section{Conclusions}

This review finds that the clinical preoperative evaluation and screening of patients with the use of DISE, as a pivotal role in decision making of surgical intervention, is vital. True decision making towards specific surgery is critical, and whilst different approaches towards these specific sites exists and all show promising results, further research in surgical management of obstructive sleep apnea is needed, especially with standardized preoperative evaluation, further patient related outcome measures, longer follow-up time and a higher number of patients included for each study.

\section{Discussion}

This systematic review included 10 studies, recruiting 697 patients with primarily moderate to severe OSA. Based upon the level of surgery, the final included studies were divided into three groups, which represent the velum and oropharynx, base of tongue and multilevel surgery. The meta-analysis in this systematic review found statistically significant reductions of both AHI and ESS. Based on the level of surgery, velum and oropharynx surgery reduced AHI with mean $11.86(95 \% \mathrm{Cl} ; 10.21 ; 13.51)$ event/hour and ESS was reduced $7.01(95 \% \mathrm{Cl} 5.99 ; 8.04)$. In BOT surgery AHI was reduced with a mean of 19.31 (95\% Cl $17.81 ; 20.81)$ events/hour and ESS decreased with mean $7.03(95 \% \mathrm{Cl} 6.44 ; 7.63)$. Multilevel surgery reduced $\mathrm{AHI}$ with 28.65 (95\% $\mathrm{Cl} 24.60,32.69)$ events/hour and ESS with $8.55(95 \% \mathrm{Cl} 6.73 ; 10.38)$. Almost all studies included only patients when CPAP treatment had failed, therefore a non-surgical control group did not exist.

Sundaram et. al reviewed surgical treatment compared to CPAP treatment or non-surgical appliance therapy and did not find evidence that surgical intervention could improve OSA [12]. In comparison, this review indicates, that surgical intervention improves both clinical and subjective OSA parameters 
such as AHI and ESS, when treatment is based upon DISE findings. However surgical intervention is limited to the procedures presented. This comparison also advocates that surgical intervention is suitable for patients non-compliant to CPAP treatment.

Each study varies in preoperative and postoperative evaluation of each patient and inclusion criteria, exclusion criteria, surgical outcome, and patient followup time. Hence, heterogeneity exists between the final studies presented here. However, common parameters in the studies are also present. Surgical outcomes are primarily AHI and ESS, while terms such as surgical responders and surgical success is described using Sher's criteria, providing a suitable comparison between the studies. DISE findings are essential, furthermore all studies use age, BMI, and the severity of OSA to screen patients before surgery. Some studies include clinical observations related to the Friedman staging system [43]. Hence, the studies are comparable although risk of bias is present. Furthermore, all studies present in detail minor and severe adverse effects to surgery.

Weaver et al. showed that PSG parameters such as AHI does not correlate well to patient related outcome [44]. In sleep related surgery, patient related outcome is essential to address the benefits of the surgical intervention. All studies except Cammaroto present ESS data. Thaler et al. report ESS, however only 31 patients of 75 patients completed ESS measurements, hence the data was not included in the meta-analysis. Some studies include additional patient related outcome measurement tools such as the SAQLI or FOSQ or merely VAS snoring scale. This review found an overall improvement in ESS. Lee et. al reported that ESS should not be used as a screening method in a population with sleep disorders since the method is unreliable [45]. However, this measurement of daytime sleepiness is still usually used among sleep surgeons. Kendzerska et. al. report in a systematic review, published evidence on the psychometric properties of ESS for describing the level of daytime sleepiness in adults and report only high-quality studies on correlation between ESS and psychometric properties [46]. They suggest that ESS can be recommended for a group but not for individual-level comparisons. Our review found that ESS was comparable between the studies and that postoperative ESS improved. We suggest that other validated patient related outcome questionnaires should be included in evaluation of patients undergoing sleep surgery such as the SAQLI or FOSQ.

All studies included in this study report mean values for AHI and ESS, as well for other secondary outcomes. However, the nature of surgical intervention compels that each patient's pre-operative and postoperative data are tested and if possible, reported individually. All studies except El-Anwar et. al and Thaler et. al reported true statistical analysis (paired-t-tests). The use of the arbitrary Sher's criteria defined as reduction of $\mathrm{AHI}>50 \%$ and to a value of less than 20 events per hour is the most used measurement of individual response of any sleep surgery regarding AHI. Plaza et. al. reported $90 \%$ surgical success when using Sher's criteria, however only 33.3\% were cured (AHI<5 events per hour). They furthermore reported that seven patients failed surgical response and two of these patients' $\mathrm{AHI}$ increased. In contrary, Thaler et. al. reported merely $45 \%$ surgical success using Sher's criteria. Due to their study setup, patients with high $\mathrm{AHI}$ were included, hence mean preoperative $\mathrm{AHI}$ was high. A 50\% reduction of $\mathrm{AHI}$ in patients with relatively low $\mathrm{AHI}(22.1 \mathrm{events}$ per hour, $\mathrm{Plaza}$ et. al.) compared to $50 \%$ reduction in $\mathrm{AHI}$ in patients with relatively high $\mathrm{AHI}$ (57.5 events per hour, Thaler et. al.) is obsolete and therefore unnecessary. However, the combination of PSG data, patient related outcome and the use of Sher's criteria can illustrate the influence of sleep surgery. Unfortunately, individual changes are not reported in these publications, although this data would surely illustrate the effect of surgery further. We advocate that further research report individual changes regarding both PSG data and patient related outcome.

Although many surgical approaches exist, only a few therapeutic interventions were included in this review. For soft palate surgery, ESP, UPPP and MRFTA is reviewed and show promising results. MRFTA is suggested to treat mild OSA, while ESP and UPPP is suggested to patients with isolated lateral wall collapse of the oropharynx regardless of maximum AHI. However, Amali et. al. and Hong et. al. did not report whether CPAP treatment had been used prior any surgery. Moffa et. al recently published a systematic review and found five different approaches to address retropalatal airway collapse [47]. Although primary outcomes were improved after surgery, heterogeneity was high and therefore level of evidence for these procedures are low and further randomized studies are needed.

For base of tongue, two different approaches were addressed. Either the reduction and removal of lingual tissue with the use of coblation or TORS, or the use of hypoglossal nerve stimulation and thereby protrusion of the entire tongue synchronous with expiration during sleep. Although resection of tongue base is widely investigated, most studies are biased with either small sample sizes or short follow-up time. Babademez et. al. and Cammaroto show promising results, however, the use of UAS show compelling results, not only because of the reported effects on AHI and ESS, but also based upon three different studies with long follow-up time. Furthermore, the benefits of the UAS are that the implant can be removed if compliance is not achievable, and that the implant can be titrated to each patient individually and controlled by the patient themselves. Constantino et. al report similar improvements and success rate in their systematic review regarding UAS [9] and Tsou et. al. recently published a systematic review and found no differences in operation time, success rate or complication rate between TORS and UAS [48].

Single-step multi-level sleep surgery is a difficult and heterogeneous entity to observe and to compare. This review found three studies suitable for review, although they vary greatly in study design and the surgical interventions used. Cammaroto et. al used tonsillectomy, ESPL, TORS BOT surgery and septoturbinoplasty, El-Anwar et. al. included hyoid suspension and a specific pharyngeal suture technique introduced by the first author, whereas Thaler et. al. combined TORS with traditional UPPP. Except Cammaroto et. al, who did not study other parameters, all studies showed statistically significant reduction in $\mathrm{AHI}$ and in ESS. Secondary outcomes were also improved. Although all three studies included DISE, the specific findings were not reported. It is therefore important not to compare the studies regarding the surgical approaches, but to consider the fact, that clinical screening and evaluation of the patient with the use of DISE is of uttermost importance, before selecting surgical approach. This causing a personal and individual approach to each patient, where single step multi-level surgery should be one of these modalities. In the multi-level group mean preoperative AHI was among the highest compared to all the studies in this review. This illustrates, that severe OSA usually is comprised by several anatomical collapses, and a multi-level approach is usually preferred among surgeons. However, this individual approach makes it more difficult to perform randomized prospective studies in the future. Gouveia et. al. recently published the overall trend in research in obstructive sleep apnea[49]. They reported that although the number of published studies regarding OSA increased over time, the level of evidence in published studies remain stationary. Remarkably, the majority of studies published are medical research of OSA and usually otolaryngology journal articles were less likely to be grant funded, or NIH funded. However, the level of evidence did not differ between medical publications and

Page 9/22 
otolaryngology publications. The process of this systematic review, illustrate that although many publications exist, only few were included in the final appraisal.

Our inclusion criteria with at least 40 patients in a study excluded a lot of interesting studies. All studies regarding Maxillomandibular advancement (MMA) surgery was excluded even if MMA surgery in minor studies have shown a great and sustained reduction in AHI in a selected group of patients with OSA and maxillar or mandibular hypoplasia[50].

\section{Declarations}

Ethical Approval and Consent to participate

Not applicable

Consent for publication

Not applicable

Availability of supporting data

Can be provided upon request.

Competing interests

None

Funding

KZG received a grant from Fund for the advancement of health research in Central Denmark Region.

Authors' contributions

Jannik Buus Bertelsen (JBB) and Kasra Zaina-Gill (KZ) and Therese Ovesen (TO) have planned the study. JBB and KZ have screened and selected the titles and abstracts of relevant studies. JBB and KZ have read the full text of the selected studies to identify studies eligible for the systematic review. JBB, KZ and TO have all contributed to the writing of the systematic review.

Acknowledgements

Not applicable

Authors' information

Bertelsen $\mathrm{JB}^{1}$, Ovesen $\mathrm{T}^{1+2}$, Zainali-Gill $\mathrm{K}^{1}$

1. University Clinic for Flavour, Balance and Sleep, Dept. ORL-HN surgery, Region Hospital West Jutland, Denmark

2.Department of Clinical Medicine, Aarhus University, Denmark

Jannik Buus Bertelsen, jannik.bertelsen@auh.rm.dk

Kasra Zaina-Gill; kasrzain@rm.dk

Therese Ovesen; theroves@rm.dk

\section{References}

1. Peppard PE, Young T, Barnet JH, Palta M, Hagen EW, Hla KM. Increased prevalence of sleep-disordered breathing in adults. Am J Epidemiol. 2013;177:1006-14. https://doi.org/10.1093/aje/kws342.

2. Heinzer R, Vat S, Marques-Vidal P, Marti-Soler H, Andries D, Tobback N, et al. Prevalence of sleep-disordered breathing in the general population: THE HypnoLaus study. The Lancet Respiratory Medicine. 2015;3:310-8. https://doi.org/10.1016/S2213-2600(15)00043-0.

3. Rotenberg BW, Murariu D, Pang KP. Trends in CPAP adherence over twenty years of data collection: a flattened curve 2016. https://doi.org/10.1186/s40463-016-0156-0.

4. Rosenberg R, Doghramji P. Optimal treatment of obstructive sleep apnea and excessive sleepiness. Advances in Therapy. 2009;26:295-312. https://doi.org/10.1007/s12325-009-0016-7.

5. Croft CB, Pringle M. Sleep nasendoscopy: a technique of assessment in snoring and obstructive sleep apnoea. Clin Otolaryngol Allied Sci. 2009;16:504-9. https://doi.org/10.1111/j.1365-2273.1991.tb02103.x.

Page $10 / 22$ 
6. Soares D, Sinawe H, Folbe AJ, Yoo G, Badr S, Rowley JA, et al. Lateral Oropharyngeal Wall and Supraglottic Airway Collapse Associated With Failure in Sleep Apnea Surgery. Laryngoscope 2012;122. https://doi.org/10.1002/lary.22474.

7. Rabelo FAW, Braga A, Küpper DS, de Oliveira JAA, Lopes FM, de Lima Mattos PLV, et al. Propofol-induced sleep: Polysomnographic evaluation of patients with obstructive sleep apnea and controls. Otolaryngol Head Neck Surg. 2010;142:218-24. https://doi.org/10.1016/j.otohns.2009.11.002.

8. Borek RC, Thaler ER, Kim C, Jackson N, Mandel JE, Schwab RJ. Quantitative airway analysis during drug-induced sleep endoscopy for evaluation of sleep apnea. Laryngoscope. 2012;122:2592-9. https://doi.org/10.1002/lary.23553.

9. Costantino A, Rinaldi V, Moffa A, Luccarelli V, Bressi F, Cassano M, et al. Hypoglossal nerve stimulation long-term clinical outcomes: a systematic review and meta-analysis. Sleep Breathing. 2020;24:399-411. https://doi.org/10.1007/s11325-019-01923-2.

10. Justin GA, Chang ET, Camacho M, Brietzke SE. Transoral Robotic Surgery for Obstructive Sleep Apnea: A Systematic Review and Meta-Analysis. Otolaryngology-Head Neck Surgery. 2016;154:835-46. https://doi.org/10.1177/0194599816630962.

11. Miller SC, Nguyen SA, Ong AA, Gillespie MB. Transoral robotic base of tongue reduction for obstructive sleep apnea: A systematic review and metaanalysis. Laryngoscope. 2017;127:258-65. https://doi.org/https://doi.org/10.1002/lary.26060.

12. Sundaram S, Lim J, Lasserson TJ. Surgery for obstructive sleep apnoea in adults. Cochrane Database of Systematic Reviews. 2005. https://doi.org/10.1002/14651858.cd001004.pub2.

13. Werz SM, Pfeifle M, Schrader F, Jurgens P, Briel M, Berg BI. Surgery for obstructive sleep apnoea in adults. Cochrane Database of Systematic Reviews 2017;2017. https://doi.org/10.1002/14651858.CD012770.

14. Sher AE, Schechtman KB, Piccirillo JF. The efficacy of surgical modifications of the upper airway in adults with obstructive sleep apnea syndrome. Sleep. 1996;19:156-77. https://doi.org/10.1093/sleep/19.2.156.

15. Aromataris EMZ. JBI Manual for Evidence Synthesis. 2020.

16. Lockwood C, Porrit K, Munn Z, Rittenmeyer L, Salmond S, Bjerrum M, Loveday H, Carrier JSD. JBI Manual for Evidence Synthesis. 2020.

17. Ouzzani M, Hammady H, Fedorowicz Z, Elmagarmid A. Rayyan-a web and mobile app for systematic reviews. Systematic Reviews. 2016;5:210. https://doi.org/10.1186/s13643-016-0384-4.

18. Munn Z, Aromataris E, Tufanaru C, Stern C, Porritt K, Farrow J, et al. The development of software to support multiple systematic review types: the Joanna Briggs Institute System for the Unified Management, Assessment and Review of Information (JBI SUMARI). JBI Evidence Implementation 2019;17.

19. Fujita S.. Ear. UPPP for sleep apnea and snoring. Nose Throat Journal. 1984;63:227-35.

20. Browaldh N, Bring J, Friberg D. SKUP3: 6 and 24 months follow-up of changes in respiration and sleepiness after modified UPPP. Laryngoscope. 2018;128:1238-44. https://doi.org/10.1002/lary.26835.

21. Pang KP, Woodson BT, Woodson B. Expansion sphincter pharyngoplasty: a new technique for the treatment of obstructive sleep apnea. OtolaryngologyHead Neck Surgery: Official Journal of American Academy of Otolaryngology-Head Neck Surgery. 2007;137:110-4. https://doi.org/10.1016/j.otohns.2007.03.014.

22. Vicini C, Hendawy E, Campanini A, Eesa M, Bahgat A, AlGhamdi S, et al. Barbed reposition pharyngoplasty (BRP) for OSAHS: a feasibility, safety, efficacy and teachability pilot study. "We are on the giant's shoulders. Eur Arch Otorhinolaryngol. 2015;272:3065-70. https://doi.org/10.1007/s00405-015-3628-3.

23. Powell NB, Riley RW, Troell RF, Li K, Blumen MB, Guilleminault C. clinical investigations Radiofrequency Volumetric Tissue Reduction of the Palate in Subjects With Sleep-Disordered Breathing*. vol. 113. 1998. https://doi.org/10.1378/chest.113.5.1163.

24. Wischhusen J, Qureshi U, Camacho M. Laser-assisted uvulopalatoplasty (LAUP) complications and side effects: A systematic review. Nature Science of Sleep. 2019;11:59-67. https://doi.org/10.2147/NSS.S178540.

25. Chang ET, Kwon Y-D, Jung J, Capasso R, Riley R, Liu SC, et al. Genial tubercle position and genioglossus advancement in obstructive sleep apnea (OSA) treatment: a systematic review. Maxillofacial Plastic Reconstructive Surgery. 2019;41:34. https://doi.org/10.1186/s40902-019-0217-1.

26. Guilleminault, Powell N, Riley R, Guilleminault C. Radiofrequency tongue base reduction in sleep-disordered breathing: A pilot study. Otolaryngology-Head Neck Surgery: Official Journal of American Academy of Otolaryngology-Head Neck Surgery. 1999;120:656-64. https://doi.org/10.1053/hn.1999.v120.a96956.

27. Handler E, Hamans E, Goldberg AN, Mickelson S. Tongue suspension. Laryngoscope. 2014;124:329-36. https://doi.org/10.1002/lary.24187.

28. Vicini C, Dallan I, Canzi P, Frassineti S, la Pietra MG, Montevecchi F. Transoral robotic tongue base resection in obstructive sleep apnoea-hypopnoea syndrome: a preliminary report. ORL; Journal for Oto-Rhino-Laryngology and Its Related Specialties 2010;72:22-7. https://doi.org/10.1159/000284352.

29. Eisele DW, Smith PL, Alam DS, Schwartz AR. Direct hypoglossal nerve stimulation in obstructive sleep apnea. Archives of Otolaryngology-Head Neck Surgery. 1997;123:57-61. https://doi.org/10.1001/archotol.1997.01900010067009.

30. Plaza G, Baptista P, O’Connor-Reina C, Bosco G, Pérez-Martín N, Pang KP. Prospective multi-center study on expansion sphincter pharyngoplasty. Acta Otolaryngol. 2019;139:219-22. https://doi.org/10.1080/00016489.2018.1533992.

31. Amali A, Motiee-Langroudi M, Saedi B, Rahavi-Ezabadi S, Karimian A, Amirzargar B. A comparison of uvulopalatopharyngoplasty and modified radiofrequency tissue ablation in mild to moderate obstructive sleep apnea: A randomized clinical trial. J Clin Sleep Med. 2017;13:1089-96. https://doi.org/10.5664/jcsm.6730.

32. Hong SN, Kim HG, Han SY, Ji JY, Kim MK, Han DH, et al. Indications for and Outcomes of Expansion Sphincter Pharyngoplasty to Treat Lateral Pharyngeal Collapse in Patients with Obstructive Sleep Apnea. JAMA Otolaryngology - Head Neck Surgery. 2019;145:405-12.

https://doi.org/10.1001/jamaoto.2019.0006.

33. Babademez MA, Gul F, Sancak M, Kale H. Prospective randomized comparison of tongue base resection techniques: Robotic vs coblation. Clin Otolaryngol. 2019;44:989-96. https://doi.org/10.1111/coa.13424.

Page 11/22 
34. Strollo PJ, Soose RJ, Maurer JT, de Vries N, Cornelius J, Froymovich O, et al. Upper-Airway Stimulation for Obstructive Sleep Apnea. N Engl J Med. 2014;370:139-49. https://doi.org/10.1056/nejmoa1308659.

35. Huntley C, Kaffenberger T, Doghramji K, Soose R, Boon M. Upper airway stimulation for treatment of obstructive sleep apnea: An evaluation and comparison of outcomes at two academic centers. J Clin Sleep Med. 2017;13:1075-9. https://doi.org/10.5664/jcsm.6726.

36. Steffen A, Sommer JU, Hofauer B, Maurer JT, Hasselbacher K, Heiser C. Outcome after one year of upper airway stimulation for obstructive sleep apnea in a multicenter German post-market study. Laryngoscope. 2018;128:509-15. https://doi.org/10.1002/lary.26688.

37. Heiser C, Maurer JT, Hofauer B, Sommer JU, Seitz A, Steffen A. Outcomes of Upper Airway Stimulation for Obstructive Sleep Apnea in a Multicenter German Postmarket Study. Otolaryngol Head Neck Surg. 2017;156:378-84. https://doi.org/10.1177/0194599816683378.

38. Cammaroto G, Meccariello G, Costantini M, Stomeo F, Hoff P, Montevecchi F, et al. Trans-oral robotic tongue reduction for OSA: Does lingual anatomy influence the surgical outcome? J Clin Sleep Med. 2018;14:1347-51. https://doi.org/10.5664/jcsm.7270.

39. Meccariello G, Cammaroto G, Montevecchi F, Hoff PT, Spector ME, Negm H, et al. Transoral robotic surgery for the management of obstructive sleep apnea: a systematic review and meta-analysis. Eur Arch Otorhinolaryngol. 2017;274:647-53. https://doi.org/10.1007/s00405-016-4113-3.

40. El-Anwar MW, El-Ahl M, El-Anwar M. Expansion Pharyngoplasty by New Simple Suspension Sutures without Tonsillectomy. Otolaryngology-Head and Neck Surgery. Official Journal of American Academy of Otolaryngology-Head Neck Surgery. 2016;155:1065-8.

https://doi.org/10.1177/0194599816669501.

41. El-Anwar MW, El-Ahl M, El-Anwar M. Expansion Pharyngoplasty by New Simple Suspension Sutures without Tonsillectomy. Otolaryngology-Head and Neck Surgery. Official Journal of American Academy of Otolaryngology-Head Neck Surgery. 2016;155:1065-8. https://doi.org/10.1177/0194599816669501.

42. Thaler ER, Rassekh CH, Lee JM, Weinstein GS, O’Malley BW. Outcomes for multilevel surgery for sleep apnea: Obstructive sleep apnea, transoral robotic surgery, and uvulopalatopharyngoplasty. Laryngoscope. 2016;126:266-9. https://doi.org/10.1002/lary.25353.

43. Friedman M, Salapatas AM, Bonzelaar LB. Updated Friedman Staging System for Obstructive Sleep Apnea. Adv Otorhinolaryngol. 2017;80:41-8. https://doi.org/10.1159/000470859.

44. Weaver EM, Woodson BT, Steward DL. Polysomnography indexes are discordant with quality of life, symptoms, and reaction times in sleep apnea patients. Otolaryngology-Head Neck Surgery: Official Journal of American Academy of Otolaryngology-Head Neck Surgery. 2005;132:255-62. https://doi.org/10.1016/j.otohns.2004.11.001.

45. Lee JL, Chung Y, Waters E, Vedam H. The Epworth sleepiness scale: Reliably unreliable in a sleep clinic population. J Sleep Res. 2020;29:e13019. https://doi.org/https://doi.org/10.1111/jsr.13019.

46. Kendzerska TB, Smith PM, Brignardello-Petersen R, Leung RS, Tomlinson GA. Evaluation of the measurement properties of the Epworth sleepiness scale: a systematic review. Sleep Med Rev. 2014;18:321-31. https://doi.org/10.1016/j.smrv.2013.08.002.

47. Moffa A, Rinaldi V, Mantovani M, Pierri M, Fiore V, Costantino A, et al. Different barbed pharyngoplasty techniques for retropalatal collapse in obstructive sleep apnea patients: a systematic review. Sleep Breathing = Schlaf Atmung. 2020;24:1115-27. https://doi.org/10.1007/s11325-020-02088-z.

48. Tsou Y-A, Chang W-D. Comparison of transoral robotic surgery with other surgeries for obstructive sleep apnea. Scientific Reports | 123AD;10:18163. https://doi.org/10.1038/s41598-020-75215-1.

49. Gouveia CJ, Zaghi S, Awad M, Camacho M, Liu SYC, Capasso R, et al. Publication trends and levels of evidence in obstructive sleep apnea literature. Laryngoscope. 2018;128:2193-9. https://doi.org/https://doi.org/10.1002/lary.27075.

50. Boyd SB, Walters AS, Waite P, Harding SM, Song Y. Long-term effectiveness and safety of maxillomandibular advancement for treatment of obstructive sleep apnea. J Clin Sleep Med. 2015;11:699-708. https://doi.org/10.5664/jcsm.4838.

\section{Tables}

LOE (level of evidence) is based on Levels of Evidence for effectiveness developed by the Joanna Briggs Institute for experimental and quasi-experimental designs.

$\mathrm{BMI}=$ Body Mass Index

ASA = American Society of Anesthesiology score

$\mathrm{AHI}=$ Apnea hypopnea Index

ODI = Oxygen Desaturation Index

ESS $=$ Epworth Sleepiness Scale

FOSQ = Functional Outcomes of sleep questionnaire.

TST $=$ Total sleep time 


\begin{tabular}{|c|c|c|c|c|c|c|c|c|c|}
\hline \multicolumn{10}{|c|}{ Study's general characteristics } \\
\hline Author, year & $\begin{array}{l}\text { Type of } \\
\text { study }\end{array}$ & $\begin{array}{l}\text { Follow- } \\
\text { up in } \\
\text { months }\end{array}$ & $\begin{array}{l}\text { Mean age } \\
\text { of patients } \\
\text { (no. of } \\
\text { patients) }\end{array}$ & $\begin{array}{l}\text { Mean BMI } \\
\text { (sd) }\end{array}$ & $\begin{array}{l}\text { Inclusion } \\
\text { criteria }\end{array}$ & $\begin{array}{l}\text { Exclusion } \\
\text { criteria }\end{array}$ & $\begin{array}{l}\text { Outcomes } \\
\text { analyzed }\end{array}$ & LOE & Comments \\
\hline Plaza 2019 & $\begin{array}{l}\text { Prospective } \\
\text { multi-center } \\
\text { cohort study }\end{array}$ & 12 & $\begin{array}{l}46.7 \pm 10.5 \\
(75)\end{array}$ & $28.1(2.7)$ & $\begin{array}{l}\text { CPAP failure, } \\
\text { age between } \\
18 \text { and } 75, \\
\text { BMI } \leq 35 \text {, } \\
\text { ASA } \leq 2 \text {, AHI 5- } \\
70 \text {, lateral wall } \\
\text { collapse on } \\
\text { oropharynx }\end{array}$ & $\begin{array}{l}\text { Age } \geq 75 \text {, } \\
\text { severe medical } \\
\text { illness, limited } \\
\text { mouth } \\
\text { opening } \leq 2 \mathrm{~cm} \\
\text { Tonsil size } \geq 3 \text {, } \\
\text { FTP } \geq 3 \text {, } \\
\text { LTH } \geq 3 \text { and } \\
\text { follow-up } \\
\text { under } 12 \\
\text { months. }\end{array}$ & $\begin{array}{l}\text { AHI, ESS, } \\
\text { Surgical } \\
\text { success }\end{array}$ & $2 d$ & Polysomnography \\
\hline Amali 2017 & $\begin{array}{l}\text { Randomized } \\
\text { controlled } \\
\text { trial }\end{array}$ & 6 & $\begin{array}{l}37.4 \pm 10.07 \\
(40)\end{array}$ & $27.7(4.3)$ & $\begin{array}{l}\text { Age> } 18 \text {, } \\
\text { Symptomatic } \\
\text { OSA with } \\
5 \leq \text { AHI30, No } \\
\text { prior } \\
\text { treatment, } \\
\text { BMI } \leq 35 \text {, ASA } \\
\leq 3\end{array}$ & $\begin{array}{l}\text { AHI } \geq 30 \text {, } \\
\text { Tongue base } \\
\text { or epiglottis } \\
\text { obstruction, } \\
\text { previous } \\
\text { history of } \\
\text { palatal } \\
\text { surgery, severe } \\
\text { comorbidities, } \\
\text { depression }\end{array}$ & $\begin{array}{l}\text { AHI, Nadir O2, } \\
\text { Mean O2, ESS, } \\
\text { SAQLI }\end{array}$ & $1 \mathrm{c}$ & Polysomnography \\
\hline Hong 2019 & Cohort study & 6 & $\begin{array}{l}42.1 \text { (range } \\
20-54)(63)\end{array}$ & $\begin{array}{l}27.58 \\
\text { (range 19- } \\
32.1 \text { ) }\end{array}$ & $\begin{array}{l}\text { AHI>15, } \\
\text { retropalatal } \\
\text { circumferential } \\
\text { narrowing } \\
\text { above DISE } \\
\text { grade II (>75\% } \\
\text { narrowing), } \\
\text { narrowed } \\
\text { oropharynx } \\
\text { due to lateral } \\
\text { pharyngeal } \\
\text { collapse }\end{array}$ & $\begin{array}{l}\text { None } \\
\text { mentioned }\end{array}$ & $\begin{array}{l}\text { AHI, Nadir O2, } \\
\text { VAS snoring, } \\
\text { surgical } \\
\text { success, CT- } \\
\text { scan }\end{array}$ & $2 d$ & $\begin{array}{l}\text { Polysomnography. } \\
\text { Patients underwent } \\
\text { different surgical } \\
\text { treatments such as } \\
\text { septoplasty and } \\
\text { UP-flap prior } \\
\text { treatment. }\end{array}$ \\
\hline \multirow{2}{*}{$\begin{array}{l}\text { Babademez } \\
2019\end{array}$} & \multirow{2}{*}{$\begin{array}{l}\text { Randomized } \\
\text { controlled } \\
\text { trial }\end{array}$} & \multirow[t]{2}{*}{6} & TORS & TORS & \multirow{2}{*}{$\begin{array}{l}\text { CPAP failure, } \\
\text { moderate to } \\
\text { severe OSA, } \\
\text { BMI } \leq 35 \text {, tonsil } \\
\text { size } 1-2\end{array}$} & \multirow[b]{2}{*}{$\begin{array}{l}\text { Limited mouth } \\
\text { opening, } \\
\text { severe } \\
\text { comorbidities, } \\
\text { known } \\
\text { bleeding } \\
\text { disorder, } \\
\text { previous } \\
\text { tonsillectomy, } \\
\text { lost to follow- } \\
\text { up }\end{array}$} & \multirow{2}{*}{$\begin{array}{l}\text { AHI, ESS, VAS } \\
\text { snoring, } \\
\text { surgical } \\
\text { success, time } \\
\text { to oral diet, } \\
\text { analgesic } \\
\text { requirement }\end{array}$} & \multirow[t]{2}{*}{$1 c$} & \multirow[t]{2}{*}{ Polysomnography } \\
\hline & & & $\begin{array}{l}40.9 \pm 9.2 \\
(37) \\
\text { Coblation } \\
39.4 \pm 8.5 \\
(33)\end{array}$ & $28.3 \pm 3.9$ & & & & & \\
\hline $\begin{array}{l}\text { Strollo } \\
2014\end{array}$ & $\begin{array}{l}\text { Prospective } \\
\text { multi-center } \\
\text { cohort study }\end{array}$ & 12 & $\begin{array}{l}54.5 \pm 10.2 \\
(126)\end{array}$ & $28.4 \pm 2.6$ & $\begin{array}{l}\text { CPAP failure, } \\
\text { moderate to } \\
\text { severe OSA. } \\
\text { No concentric } \\
\text { collapse in } \\
\text { oropharynx } \\
\text { during DISE }\end{array}$ & $\begin{array}{l}\text { BMI > 32, } \\
\text { neuromuscular } \\
\text { disease, } \\
\text { hypoglossal } \\
\text { nerve palsy, } \\
\text { pulmonal } \\
\text { disease, } \\
\text { moderate-to - } \\
\text { severe } \\
\text { hypertension, } \\
\text { NYHA 3-4, } \\
\text { recent } \\
\text { myocardial } \\
\text { infarction or } \\
\text { severe cardiac } \\
\text { arrhythmias, } \\
\text { active } \\
\text { psychiatric } \\
\text { disease, } \\
\text { nonrespiratory } \\
\text { sleep disorder. }\end{array}$ & $\begin{array}{l}\text { AHI, ODI, FOSQ, } \\
\text { ESS, \% of TST } \\
\text { with O2<90\%, } \\
\text { surgical } \\
\text { success }\end{array}$ & $2 d$ & $\begin{array}{l}\text { Polysomnography. } \\
\text { STAR-trial funded } \\
\text { by implant } \\
\text { company. }\end{array}$ \\
\hline \multirow{4}{*}{$\begin{array}{l}\text { Huntley } \\
2017\end{array}$} & \multirow{4}{*}{$\begin{array}{l}\text { Multi-center } \\
\text { cohort study }\end{array}$} & \multirow[t]{4}{*}{3} & TJUH & TJUH & \multirow{4}{*}{$\begin{array}{l}\text { CPAP failure, } \\
\text { moderate to } \\
\text { severe OSA. } \\
\text { No concentric } \\
\text { collapse in } \\
\text { oropharynx } \\
\text { during DISE }\end{array}$} & \multirow{4}{*}{$\begin{array}{l}\text { BMI > 32, } \\
\text { neuromuscular } \\
\text { disease, } \\
\text { hypoglossal } \\
\text { nerve palsy, } \\
\text { pulmonal } \\
\text { disease, } \\
\text { moderate-to - } \\
\text { severe } \\
\text { hypertension, }\end{array}$} & \multirow{4}{*}{$\begin{array}{l}\text { AHI, ESS, Nadir } \\
\text { O2, surgical } \\
\text { success }\end{array}$} & \multirow[t]{4}{*}{$2 d$} & \multirow[t]{4}{*}{ Polysomnography } \\
\hline & & & $\begin{array}{l}60.88 \pm \\
11.12(48)\end{array}$ & $\begin{array}{l}29.29 \pm \\
3.72\end{array}$ & & & & & \\
\hline & & & UPMC & UPMC & & & & & \\
\hline & & & $\begin{array}{l}62.84 \pm \\
10.81(49)\end{array}$ & $\begin{array}{l}27.74 \pm \\
3.66\end{array}$ & & & & & \\
\hline
\end{tabular}

Page 13/22 


\begin{tabular}{|c|c|c|c|c|c|c|c|c|c|}
\hline & & & & & & $\begin{array}{l}\text { NYHA 3-4, } \\
\text { recent } \\
\text { myocardial } \\
\text { infarction or } \\
\text { severe cardiac } \\
\text { arrhythmias, } \\
\text { active } \\
\text { psychiatric } \\
\text { disease, non- } \\
\text { respiratory } \\
\text { sleep disorder. }\end{array}$ & & & \\
\hline $\begin{array}{l}\text { Steffen } \\
2018\end{array}$ & $\begin{array}{l}\text { Prospective } \\
\text { multi-center } \\
\text { cohort study }\end{array}$ & 12 & $\begin{array}{l}56.8 \pm 9.1 \\
(60)\end{array}$ & $28.8 \pm 3.6$ & $\begin{array}{l}\text { CPAP failure, } \\
\text { moderate to } \\
\text { severe OSA } \\
\text { (AHI 15-65). } \\
\text { No concentric } \\
\text { collapse in } \\
\text { oropharynx } \\
\text { during DISE }\end{array}$ & $\begin{array}{l}\text { Tonsil size 3-4 } \\
\text { Additional } \\
\text { anatomical } \\
\text { abnormalities, } \\
\text { such as long } \\
\text { soft palate. }\end{array}$ & $\begin{array}{l}\text { AHI, ODI, nadir } \\
\text { O2, mean O2, } \\
\text { ESS, FOSQ, \% } \\
\text { of TST with } \\
\text { O2<90\%, }\end{array}$ & $2 d$ & $\begin{array}{l}\text { 2-night type3 home } \\
\text { sleep test. }\end{array}$ \\
\hline $\begin{array}{l}\text { Cammaroto } \\
2018\end{array}$ & $\begin{array}{l}\text { Retrospective } \\
\text { cohort study }\end{array}$ & 12 & $\begin{array}{l}55.47 \pm \\
11.56(51)\end{array}$ & $29.12 \pm 8.9$ & $\begin{array}{l}\text { CPAP failure, } \\
\text { moderate to } \\
\text { severe OSA } \\
(\mathrm{AHI}>20)\end{array}$ & $\begin{array}{l}\text { Prior airway } \\
\text { surgery, } \\
\text { postoperative } \\
\text { PSG shorter } \\
\text { than } 12 \\
\text { months }\end{array}$ & $\begin{array}{l}\text { AHI, tongue } \\
\text { volume (cc) } \\
\text { Lymphatic/soft } \\
\text { tissue ratio, } \\
\text { total thickness, } \\
\text { surgical } \\
\text { success }\end{array}$ & $2 d$ & $\begin{array}{l}\text { Unattended type } 3 \\
\text { home sleep study } \\
\text { and } \\
\text { Polysomnography } \\
\text { used. }\end{array}$ \\
\hline $\begin{array}{l}\text { El-Anwar } \\
2018\end{array}$ & $\begin{array}{l}\text { Prospective } \\
\text { (non- } \\
\text { randomized) } \\
\text { case-control }\end{array}$ & $6-14$ & $\begin{array}{l}\text { Group A } \\
47.1 \pm 9.2 \\
(20) \\
\text { Group B } \\
46.0 \pm 4.7 \\
(20)\end{array}$ & $\begin{array}{l}\text { Group A } \\
33.4 \pm 2.5 \\
\text { Group B } \\
33.4 \pm 2.01\end{array}$ & $\begin{array}{l}\text { Moderate to } \\
\text { severe OSA } \\
(\mathrm{AHI}>15) \\
\mathrm{BMI}<35\end{array}$ & $\begin{array}{l}\text { Prior airway } \\
\text { surgery, lost to } \\
\text { follow-up. }\end{array}$ & $\begin{array}{l}\text { AHI, ESS, nadir } \\
\text { O2, Snoring } \\
\text { score }\end{array}$ & $2 d$ & $\begin{array}{l}\text { Sleep registration } \\
\text { type not stated. }\end{array}$ \\
\hline $\begin{array}{l}\text { Thaler } \\
2016\end{array}$ & $\begin{array}{l}\text { Prospective } \\
\text { non- } \\
\text { randomized } \\
\text { trial with } \\
\text { historical } \\
\text { controls. }\end{array}$ & 3 & 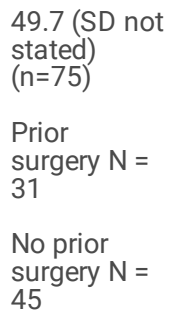 & $32.3 \pm 5.61$ & $\begin{array}{l}\text { CPAP failure, } \\
\text { moderate to } \\
\text { severe OSA } \\
(\mathrm{AHI}>20)\end{array}$ & None stated & $\begin{array}{l}\text { AHI, ESS, Nadir } \\
\text { O2, \% of TST } \\
\text { with } 02<90 \% \text {, }\end{array}$ & $2 d$ & Polysomnography. \\
\hline
\end{tabular}

LOE (level of evidence) is based on Levels of Evidence for effectiveness developed by the Joanna Briggs Institute for experimental and quasi-experimental designs.

$\mathrm{BMI}=$ Body Mass Index

ASA = American Society of Anesthesiology score

$\mathrm{AHI}=$ Apnea hypopnea Index

ODI = Oxygen Desaturation Index

ESS= Epworth Sleepiness Scale

FOSQ = Functional Outcomes of sleep questionnaire.

TST $=$ Total sleep time

\section{Figures}




\begin{tabular}{|c|c|c|c|c|c|c|c|}
\hline \multicolumn{8}{|l|}{ Study results } \\
\hline Author, year & $\begin{array}{l}\text { Pre-OP } \\
\text { AHI }\end{array}$ & $\begin{array}{l}\text { Post-OP } \\
\text { AHI }\end{array}$ & $\begin{array}{l}\text { Pre-OP } \\
\text { ESS }\end{array}$ & $\begin{array}{l}\text { Post-OP } \\
\text { ESS }\end{array}$ & $\begin{array}{l}\text { Sher's } \\
\text { surgical } \\
\text { success }\end{array}$ & Other outcomes & Comments and conclusions \\
\hline Plaza 2019 & $\begin{array}{l}22.1 \pm \\
12.2\end{array}$ & $8.6 \pm 6.7$ & $\begin{array}{l}11.5 \pm \\
4.7\end{array}$ & $4.6 \pm 6.6$ & $90 \%$ & $\begin{array}{l}33,3 \% \text { were cured }(\text { AHI }<5, \text { ESS }<10 \\
\text { and AHI reduction>50\%), } 82,66 \% \\
\text { patients did not need CPAP after } \\
\text { surgery. Using Sher's criteria } 90 \% \\
\text { obtained AHI }<20 \text {. Seven patients } \\
\text { failed surgery with two cases whose } \\
\text { AHI worsened postoperative. } \\
\text { Patients without a suitable PSG } \\
\text { postoperatively or follow-up time } \\
\text { under } 12 \text { months were excluded. }\end{array}$ & $\begin{array}{l}\text { ESP technique can be done with } \\
\text { good results as stand-alone } \\
\text { procedure for patients with OSA, } \\
\text { when proper patient selection } \\
\text { based upon DISE. }\end{array}$ \\
\hline \multirow[t]{5}{*}{ Amali 2017} & UPPP & UPPP & UPPP & UPPP & \multirow{2}{*}{$\begin{array}{l}\text { UPPP } \\
73 \%\end{array}$} & \multirow{4}{*}{$\begin{array}{l}\text { Mean SpO2 nadir in the UPPP group } \\
\text { improved from } 84,2 \% \pm 3,96 \text { to } \\
88,47 \% \pm 3,5(p<0,01) \text { and in the } \\
\text { MRFTA group improved from } \\
85,33 \% \pm 2,79 \text { to } 87 \% \pm 2,61(p<0,01) \\
\text { with no significant differences } \\
\text { between the two groups. }\end{array}$} & \multirow{5}{*}{$\begin{array}{l}\text { Authors conclude that that for } \\
\text { mild OSA, MRFTA is comparable } \\
\text { to UPPP and can be considered } \\
\text { as the first surgical treatment } \\
\text { operation in patients with } \\
\text { oropharyngeal lateral wall } \\
\text { obstruction. }\end{array}$} \\
\hline & $\begin{array}{l}20.15 \pm \\
6.92\end{array}$ & $\begin{array}{l}10.03 \pm \\
3.28\end{array}$ & $\begin{array}{l}12.07 \pm \\
3.89\end{array}$ & $\begin{array}{l}6.87 \pm \\
1.99\end{array}$ & & & \\
\hline & & & & & MRFTA & & \\
\hline & MRFTA & MRFTA & MRFTA & MRFTA & $40 \%$ & & \\
\hline & $\begin{array}{l}19.42 \pm \\
6.04\end{array}$ & $\begin{array}{l}13.39 \pm \\
4.36\end{array}$ & $\begin{array}{l}13.4 \pm \\
6.02\end{array}$ & $\begin{array}{l}7.67 \pm \\
1.71\end{array}$ & & $\begin{array}{l}\text { SAQLI improved in both groups and } \\
\text { reported higher in MFRTA group in } \\
\text { two domains including social } \\
\text { interaction and treatment-related } \\
\text { symptoms. }\end{array}$ & \\
\hline Hong 2019 & $45 . \pm 10.7$ & $\begin{array}{l}17.3 \pm \\
8.9\end{array}$ & $\begin{array}{l}17.1 \pm \\
5.4\end{array}$ & $7.2 \pm 5.4$ & N/A & $\begin{array}{l}\text { Mean SpO2 nadir improved from } \\
78,2 \% \pm 21,3 \text { to } 86,4 \% \pm 10,6 \text { with } \\
\text { reported mean difference }(95 \%) 8,6 \% \\
(6,6 \%-10,6 \% \text { Cohen } d=1,16) .\end{array}$ & $\begin{array}{l}\text { ESP appears to be a promising } \\
\text { surgical technique to reduce } \\
\text { lateral pharyngeal collapse in } \\
\text { patients with moderate or severe } \\
\text { OSA. Clinical data suggest that } \\
\text { both severe palatal } \\
\text { circumferential narrowing and } \\
\text { bulky lateral pharyngeal tissue } \\
\text { are favorable surgical } \\
\text { indications for ESP in patients } \\
\text { with OSA. }\end{array}$ \\
\hline \multirow{7}{*}{$\begin{array}{l}\text { Babademez } \\
2019\end{array}$} & TORS & TORS & TORS & TORS & TORS & \multirow{2}{*}{$\begin{array}{l}\text { Coblation scores in time to oral diet } \\
\text { were significantly better than TORS } \\
4.2 \text { days } \pm 1.2 \text { vs } 5.78 \pm \\
0.91(p=0.000)\end{array}$} & \multirow{7}{*}{$\begin{array}{l}\text { Overall, the results show } \\
\text { promising results for treatment } \\
\text { of OSA in patients with } \\
\text { moderate to severe OSA and } \\
\text { isolated tongue base obstruction } \\
\text { based upon DISE findings with } \\
\text { low risk of complications after } 6 \\
\text { months of follow-up. }\end{array}$} \\
\hline & & $\begin{array}{l}10.7 \pm \\
3.9\end{array}$ & $\begin{array}{l}12.1 \pm \\
2.7\end{array}$ & & $75.6 \%$ & & \\
\hline & Coblation & \multirow{3}{*}{$\begin{array}{l}\text { Coblation } \\
10.3 \pm 4\end{array}$} & \multirow{3}{*}{$\begin{array}{l}\text { Coblation } \\
11.4 \pm \\
2.6\end{array}$} & Coblation & Coblation & \multirow{2}{*}{$\begin{array}{l}\text { TORS scores in analgesic } \\
\text { requirement were significantly worse } \\
\text { than Coblation } 5.8 \text { days } \pm 1.8 \text { vs } \\
4.1 \pm 1.1(P=.000)\end{array}$} & \\
\hline & $27.2 \pm$ & & & $3.6 \pm 1.6$ & $78.7 \%$ & & \\
\hline & & & & & & $\begin{array}{l}\text { TORS preoperative snoring VAS } \\
7.5 \pm 1.3 \text { vs postoperative snoring } \\
\text { VAS } 2.9 \pm 1.4\end{array}$ & \\
\hline & & & & & & $\begin{array}{l}\text { Coblation preoperative snoring VAS } \\
6.9 \pm 1.4 \text { vs }\end{array}$ & \\
\hline & & & & & & postoperative snoring VAS $2.6 \pm 1$ & \\
\hline $\begin{array}{l}\text { Strollo } \\
2014\end{array}$ & $\begin{array}{l}32.0 \pm \\
11.8\end{array}$ & $\begin{array}{l}15.3 \pm \\
16.1\end{array}$ & $11.6 \pm 5$ & $7.0 \pm 4.2$ & $66 \%$ & $\begin{array}{l}\text { Mean ODI (SD) decreased from } 28,9 \\
(12) \text { to } 13,9(15,7)(p<0,001) \text {. } \\
\text { Surgical success based upon ODI } \\
\text { reduction }>25 \% \text { was } 94 \text { of } 126 \\
\text { patients }(75 \%)\end{array}$ & $\begin{array}{l}\text { The study concludes that UAS } \\
\text { showed a reduction in the } \\
\text { severity of obstructive sleep } \\
\text { apnea, and the adverse-event } \\
\text { profile was acceptable. }\end{array}$ \\
\hline
\end{tabular}




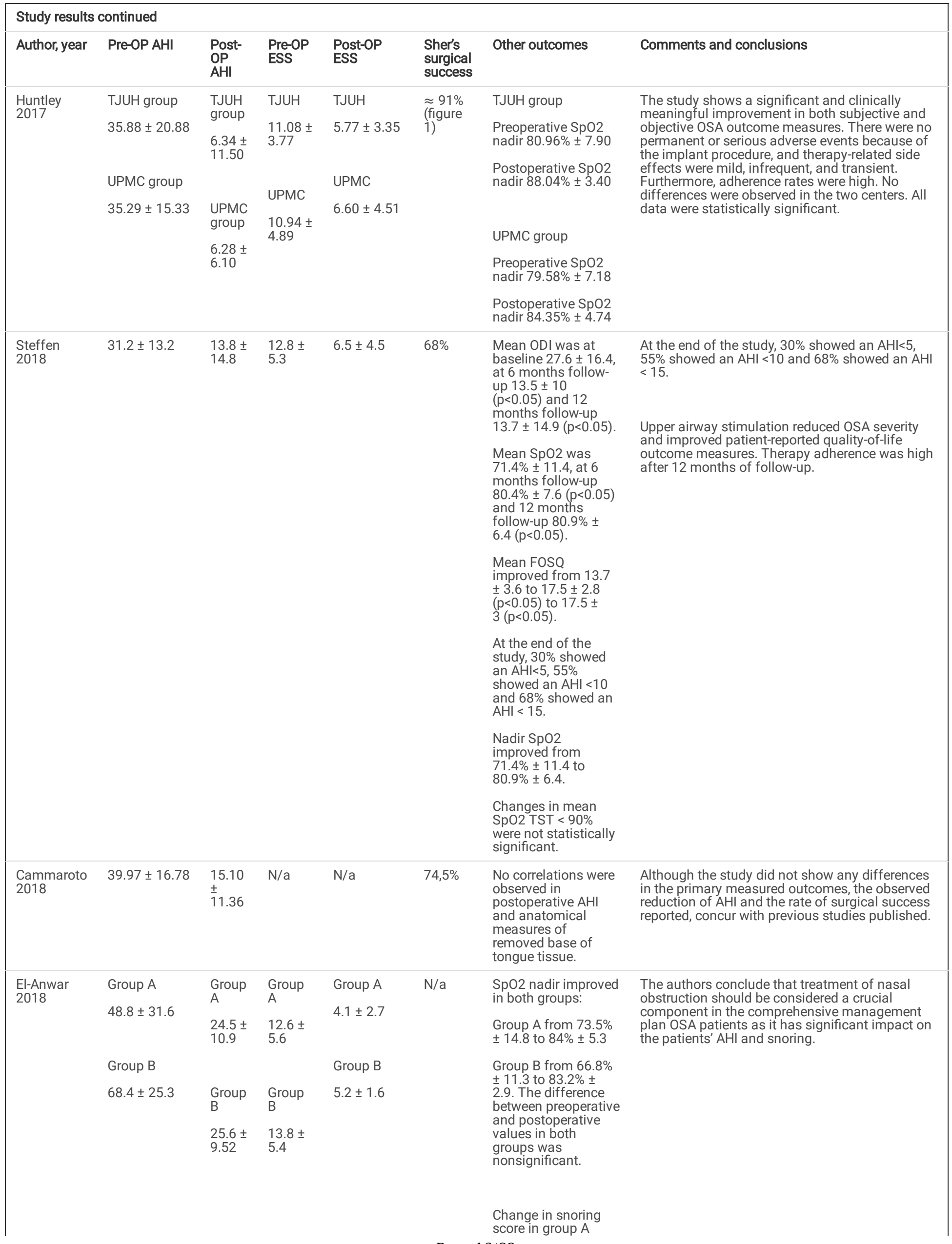

Page 16/22 
$3.8 \pm 0.4$ to $2.3 \pm$

0.51

Change in snoring

score in group $B$

$3.4 \pm 0.54$ to $2 \pm 0$.

The preoperative

snoring score was

reported to be

significantly more in

patients who had

associated nasal

obstruction (group A)

$(p=0.0113)$. But after

surgery the

difference in

postoperative

values was

nonsignificant

$(P=0.1296)$

Study results continued

\begin{tabular}{|c|c|c|c|c|c|c|c|}
\hline Author, year & Pre-OP AHI & $\begin{array}{l}\text { Post- } \\
\text { OP } \\
\text { AHI }\end{array}$ & $\begin{array}{l}\text { Pre-OP } \\
\text { ESS }\end{array}$ & $\begin{array}{l}\text { Post-OP } \\
\text { ESS }\end{array}$ & $\begin{array}{l}\text { Sher's } \\
\text { surgical } \\
\text { success }\end{array}$ & Other outcomes & Comments and conclusions \\
\hline \multirow[t]{2}{*}{$\begin{array}{l}\text { Thaler } \\
2016\end{array}$} & $57.5 \pm 23.9$ & $\begin{array}{l}31.4 \pm \\
28.6\end{array}$ & $\begin{array}{l}12.8 \pm \\
6.5\end{array}$ & $5.8 \pm 4.9$ & $45 \%$ & $\begin{array}{l}\text { SpO2 Nadir } \\
\text { improved from } \\
78.8 \% \pm 9.6 \text { to } 83.1 \% \\
\pm 7.3\end{array}$ & $\begin{array}{l}\text { The authors conclude that prior surgery did not } \\
\text { appear to make any difference in the outcome of } \\
\text { the study. Combined TORS and UPPP is suitable } \\
\text { for selected patients in a multi-level approach. }\end{array}$ \\
\hline & & & & & & $\begin{array}{l}\% \text { of TST with } \\
\text { SpO2<90\% improved } \\
\text { from } 16.9 \pm 21.3 \text { to } \\
7.2 \pm 15.3\end{array}$ & \\
\hline
\end{tabular}

PRISMEI PRISMA 2009 Flow Diagram

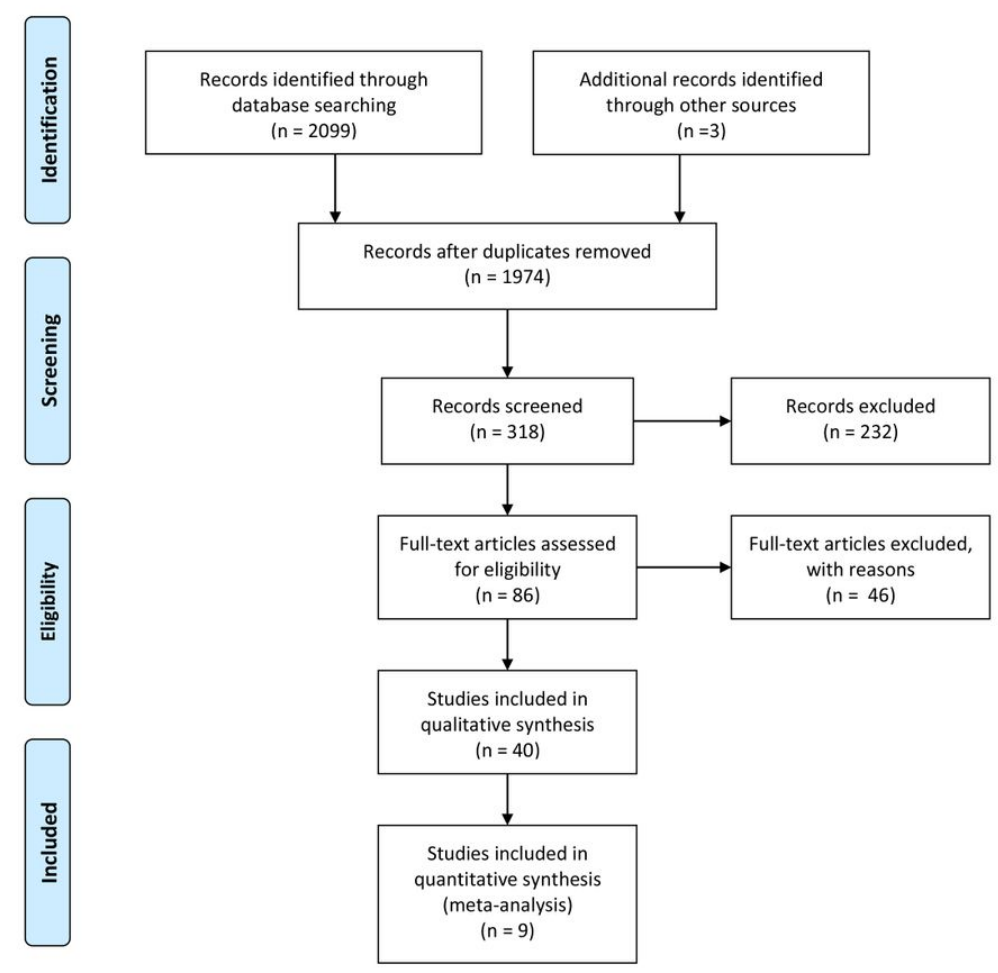

From: Moher D, Liberati A, Tetzlaff J, Altman DG, The PRISMA Group (2009). Preferred Reporting Items for Systematic Reviews and Meta-
Analyses: The PRISMA Statement. PLoS Med 6(7): e1000097. doi:10.1371/journal.pmed1000097

For more information, visit www.prisma-statement.org. 
Figure 1

flowchart

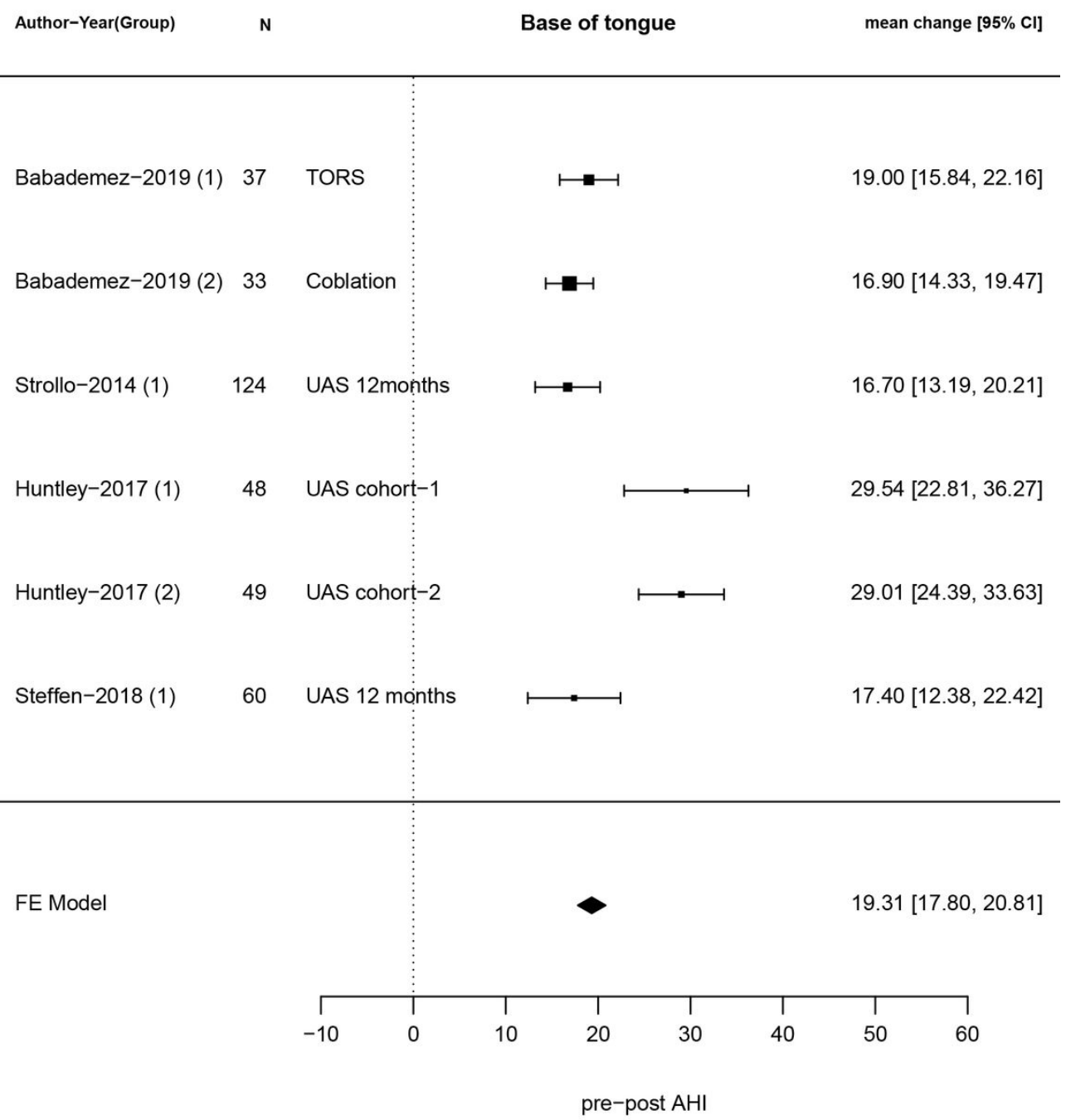

Figure 2

Forest plot AHI BOT 


\begin{tabular}{|c|c|c|c|c|c|c|c|c|}
\hline \multicolumn{2}{|c|}{ Cammaroto-2018 (1)51 } & \multirow{2}{*}{$\begin{array}{c}\text { TORS } \\
\vdots \\
\vdots \\
\text { +nasal surgery }\end{array}$} & & $\longmapsto$ & & & \multicolumn{2}{|r|}{$24.87[19.31,30.43]$} \\
\hline El-Anwar-2018 (1) & 20 & & & & & 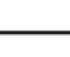 & 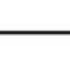 & $-43.90[31.83,55.97]$ \\
\hline El-Anwar-2018 (2) & 20 & -nasal surgery & $\longmapsto$ & & & & & $23.30[8.84,37.76]$ \\
\hline Thaler-2016 (2) & 45 & TORS+UPPP & & & & $\rightarrow$ & & 38.90 [29.97, 47.83] \\
\hline Thaler-2016 (3) & 31 & TORS* & & & & & & $10.00[-4.77,24.77]$ \\
\hline \multirow[t]{3}{*}{ FE Model } & & : & & & & & & $28.65[24.60,32.69]$ \\
\hline & & T & $T$ & $T$ & $T$ & $T$ & 1 & 7 \\
\hline & & -10 & 10 & 20 & 30 & 40 & 50 & 60 \\
\hline
\end{tabular}

Figure 3

Forest plot AHI MULTI

Author-Year(Group) N

Velum/Oropharynx

mean change $[95 \% \mathrm{Cl}]$

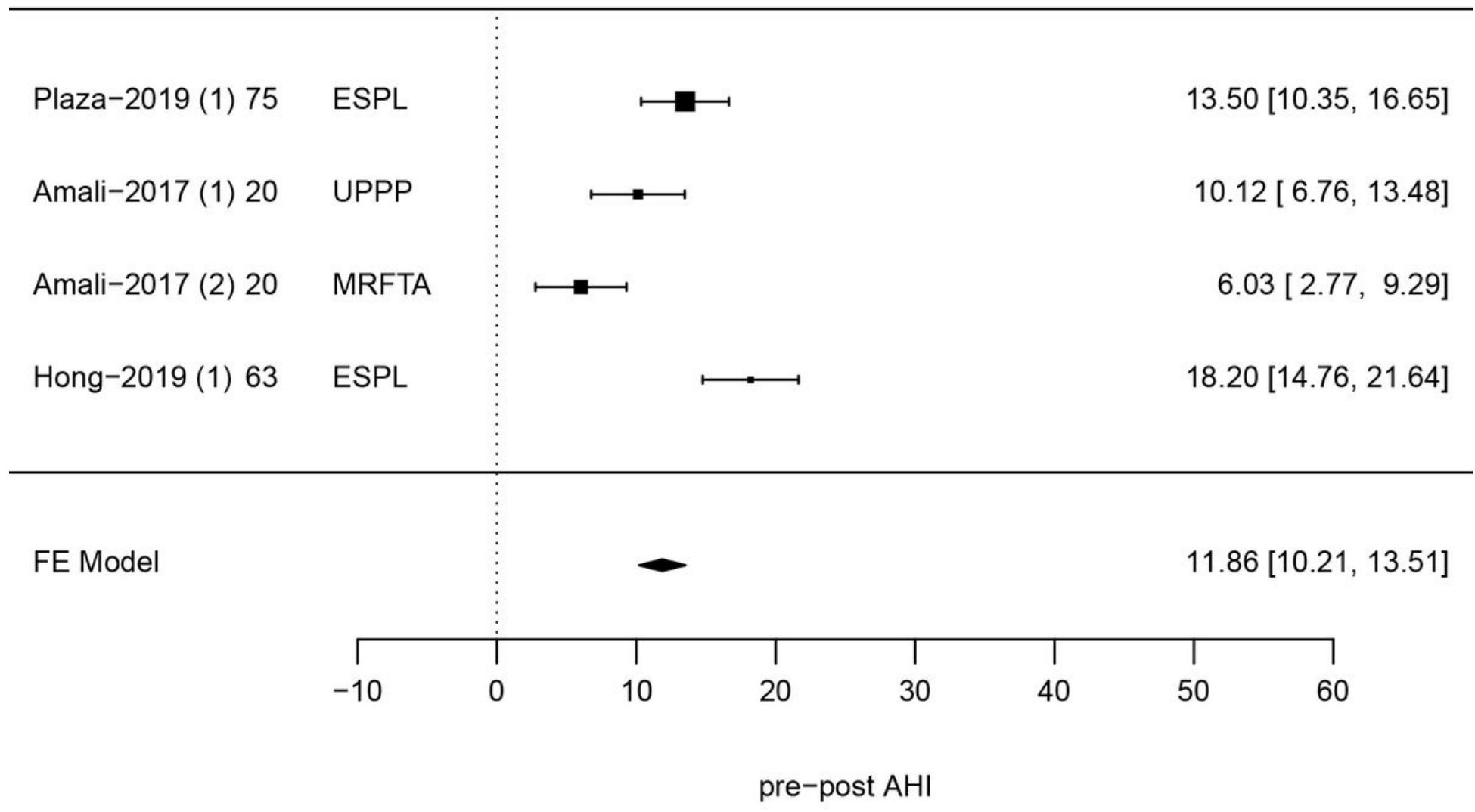


Figure 4

Forest plot AHI Velum

Author-Year(Group)

N

Base of tongue

mean change $[95 \% \mathrm{Cl}]$

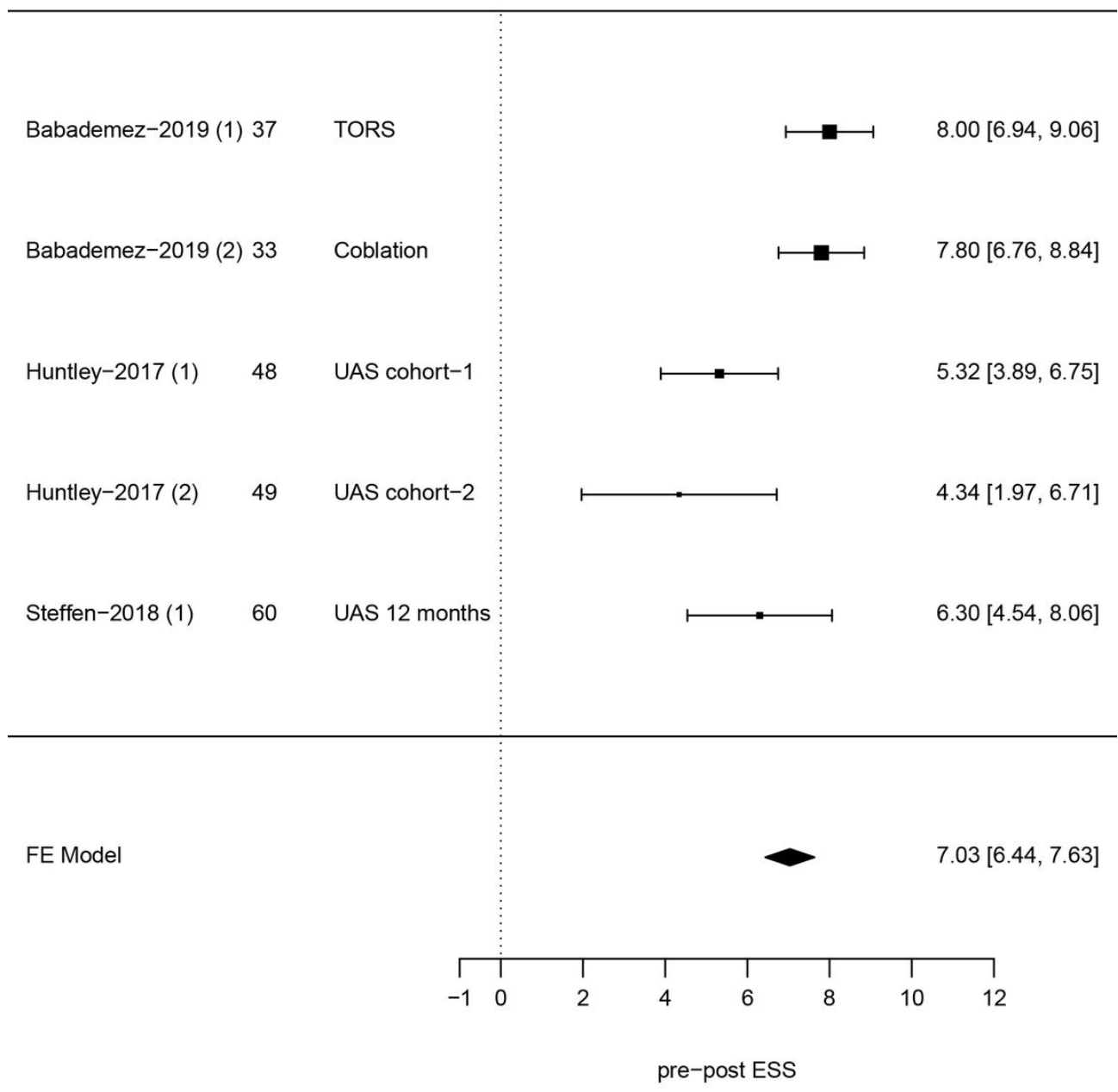

Figure 5

Forest plot ESSchange BOT 


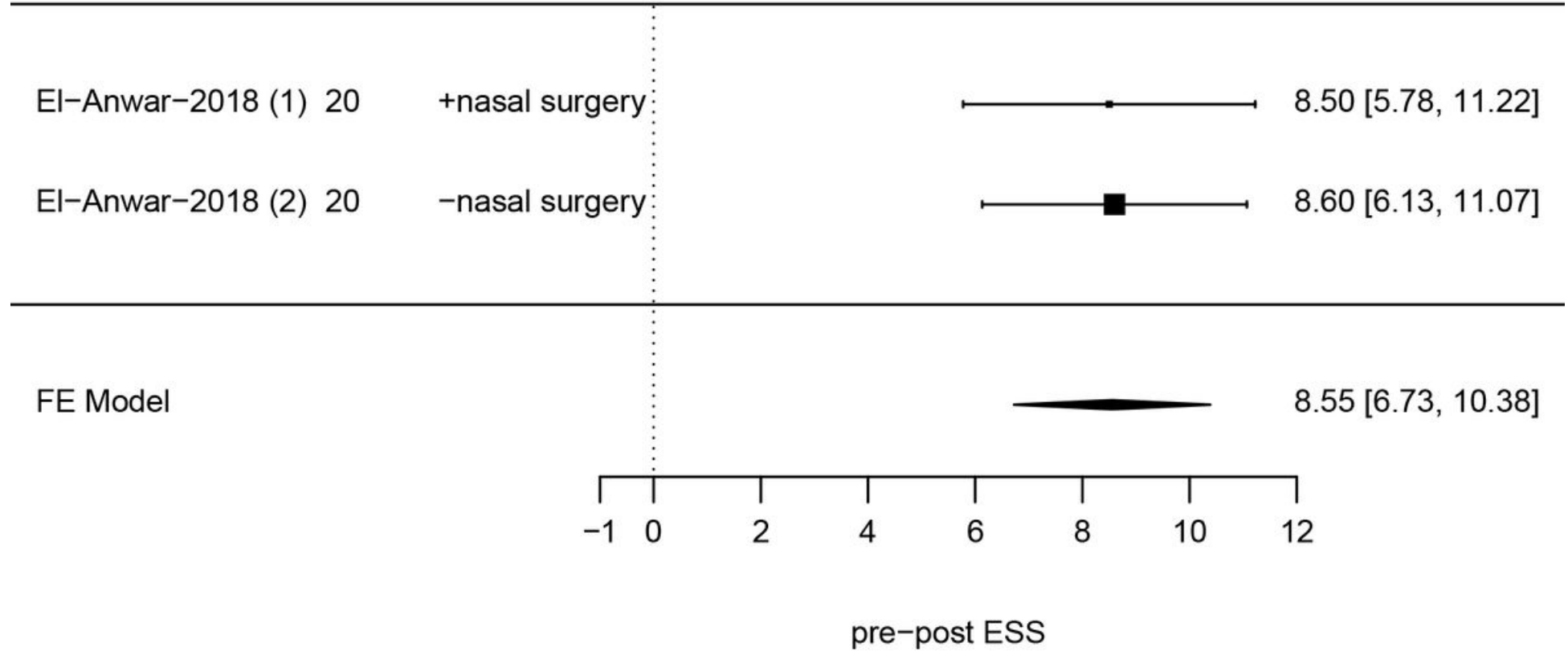

Figure 6

Forest plot ESSchange MULTI

Author-Year(Group) N

Velum/Oropharynx

mean change $[95 \% \mathrm{Cl}]$

\begin{tabular}{|c|c|c|c|c|c|c|c|c|c|}
\hline Plaza-2019 (1) 75 & ESPL & & & & - & 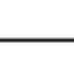 & & & $6.90[5.07,8.73]$ \\
\hline Amali-2017 (1) 20 & UPPP & & & - & - & & & & $5.20[3.29,7.11]$ \\
\hline Amali-2017 (2) 20 & MRFTA & & & & & 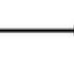 & & & $5.73[2.99,8.47]$ \\
\hline Hong-2019 (1) 63 & ESPL & & & & & $\longmapsto$ & $\rightarrow$ & 一 & $9.90[7.87,11.93]$ \\
\hline \multirow[t]{3}{*}{ FE Model } & & & & & & & & & $7.01[5.99,8.04]$ \\
\hline & Г & T & $T$ & T & $\mathrm{T}$ & $T$ & $T$ & 7 & \\
\hline & & 0 & 2 & 4 & 6 & 8 & 10 & 12 & \\
\hline
\end{tabular}

Figure 7

Forest plot ESSchange Velum

\section{Supplementary Files}

This is a list of supplementary files associated with this preprint. Click to download.

- searchhistory.docx 
- PRISMAlist.docx

Page 22/22 